\title{
Configuração epistemológica da ciência da informação no Brasil em uma perspectiva pós-moderna: análise de periódicos da área*
}

\author{
Marivalde Moacir Francelin \\ Mestre em biblioteconomia \\ e ciência da informação pela PUC-Campinas, 2004. \\ E-mail:mfrancelin@yahoo.com.br
}

\begin{abstract}
Resumo
A ciência na pós-modernidade reflete as revoluções científicas ocorridas no final do século XIX e início do século XX. As rupturas e crises paradigmáticas proporcionaram o debate em torno de uma nova ciência, na qual o desenvolvimento do conhecimento se processa através de contextos relacionais e de complexidade. A mudança na relação do sujeito com o objeto toma parte no processo de desmistificação da razão, sugerindo a necessidade de uma teoria do conhecimento aberta à transversalidade de pensamento e a quase todos os eventos de ordem e de desordem que conduzam a uma pluralidade conceitual e metodológica. Este é o contexto no qual se procura pensar a ciência da informação. Nesse sentido, o principal objetivo deste trabalho é analisar o estatuto científico da ciência da informação na pós-modernidade. O procedimento adotado partiu de um estudo epistemológico, traçando uma síntese do desenvolvimento do pensamento filosófico científico ocidental até a pósmodernidade. A seguir, procedeu-se ao levantamento e à análise de artigos selecionados em periódicos da ciência da informação no Brasil, do período de 1972-2002. Foram utilizados 37 textos, selecionados de acordo com um conjunto de categorias estabelecidas a partir do referencial teórico da pesquisa. Constatou-se que, nesse período, pouco se discutiu, em ciência da informação no Brasil, sobre as características relacionadas ao pensamento (filosófico) científico na pós-modernidade.
\end{abstract}

Palavras-chave: Ciência da informação; Epistemologia; Pós-modernidade, Ciência; Filosofia da ciência; Teoria do conhecimento.

\section{Palavras-chave}

Ciência da informação; Epistemologia; Pós-modernidade; Ciência; Filosofia da ciência; Teoria do conhecimento.

\section{Epistemological configuration of Information Science from postmodern perspective in Brazil: analysis of periodicals}

\begin{abstract}
Science in postmodernity reflects the scientific revolutions occurred in the end of the XIX century and in the beginning of XX century. The paradigmatic ruptures and crises provided the debate around a new science that develops in relational contexts of complexity. The changes, which also include new relations of the subject with the object, take part in the process of suspicion of traditional reason, suggesting the necessity of an open theory to the transversal of thought and to almost all the events that lead to conceptual and methodological plurality. This is the context in which this research about information science is developed. In this sense, the objective of this work is to analyze the scientific statute of information science in postmodernity. In the first place, an epistemological approach has been adopted, tracing a synthesis of the development of the western scientific philosophical thought up to postmodernity. Then, a survey and analysis of articles selected in journals devoted to information science in Brazil, from 1972 to 2002, were carried out. Thirty-seven texts were selected in accordance with a set of categories established from the theoretical reference framework of the research. It was evident that, during this period, little research was done in Brazil about epistemological questions related to the characteristics of the scientific philosophical thought of information science in postmodernity.

Keywords
\end{abstract}

Information science; Epistemology; Postmodernity; Science; Philosophy of science; Theory of knowledge.

\section{INTRODUÇÃO}

A presente pesquisa configura-se como um empreendimento para compreender a ciência da informação no contexto da pós-modernidade, tendo como pressuposto a idéia da impossibilidade de promover um debate sobre o estatuto científico da ciência da informação fora desse contexto. Dito de outro modo, tenta-se sustentar que a ciência da informação passa por um processo de busca paradigmática, aspecto presente em qualquer ciência na pós-modernidade.

O empreendimento proposto requer, inicialmente, a caracterização do pensamento (filosófico) científico na pós-modernidade. Esse último não se conforma a regras, dogmas ou doutrinas únicas, não havendo, portanto, um padrão único a ser seguido. Com efeito, mistura de padrões dentro de uma despadronização, o pós-moderno configura-se através do sistema e do caótico que envolve as relações e inter-relações universais. No campo da economia, da política, da cultura, das novas tecnologias e, principalmente, da ciência, essas características não passam despercebidas, pois interferem de maneira quase que determinante nessas áreas. Especificamente na ciência, o debate que a envolveu ao longo do século XX foi decisivo para sua própria desdogmatização, dirigindo-a para a busca de novos modos e versões paradigmáticos.

A partir dessas rupturas, as disciplinas científicas tendem a contextualizar-se paradigmaticamente por meio de estudos epistemológicos, de novo tipo. É isto o que se pretende fazer neste trabalho, ou seja, contextualizar a ciência da informação nesse novo cenário científico da pós-modernidade, ressaltando-se que um estudo epistemológico como o aqui proposto não pode ser definitivo.

\footnotetext{
* Artigo elaborado a partir da dissertação de mestrado "Configuração espistemológica da ciência da informação no Brasil em uma perspectiva pós-moderna”, desenvolvida por Marivalde Moacir Francelin sob a orientação da professora doutora Nair Yumiko Kobashi, junto ao Programa de Pós-Graduação em Biblioteconomia e Ciência da Informação da PUC/Campinas, 2004.
} 


\section{SÍNTESE DA HISTÓRIA DO PENSAMENTO (FILOSÓFICO) CIENTÍFICO E SEUS CONTEXTOS*}

Esta é uma breve e, evidentemente, incompleta síntese de algumas das principais características da história do pensamento (filosófico) científico ocidental. Longe da exaustão e da rigorosidade (regularidade) em datas e nomes, o principal objetivo da introdução é descrever os períodos de pensamento no Ocidente. Tenta-se, portanto, identificar quais teorias ou doutrinas foram "dominantes" na Idade Antiga (Clássica), na Idade Média, na Idade Moderna e na Idade Contemporânea.

O enfoque é dado a partir da própria ciência, manifestando já de início certa dúvida (preocupação), pois, quando se refere ao termo ciência, imediatamente surgem alguns obstáculos. Mesmo uma abordagem que se proponha a fazer apenas breve conceituação não escapa às peculiares dificuldades. Sendo a ciência certo tipo de categoria, de entidade e de conhecimento, proporciona interpretações várias, impossíveis de serem esgotadas, mesmo pela pesquisa que se defina como "completa" e exaustiva. Sempre haverá algo mais a dizer sobre a ciência (Collins \& Pinch, 2003).

No momento, o que se pode asseverar é que o conhecimento científico se desenvolve a partir do conhecimento do senso comum na tentativa de distinguir-se desse último, transformando-se em um conhecimento "seguro" e iluminando, dessa maneira, a realidade. (Luckesi \& Passos, 2002). Para assegurar essa distinção, o conhecimento científico conta com uma série de recursos, como, por exemplo, métodos e equipamentos que, provavelmente, não fazem parte do cotidiano de um indivíduo comum. Há debates em torno de um senso comum que poderia ser científico, porém, assim como não se abordará a ciência como entidade e categoria, o mesmo se aplica a assuntos em debate (Santos, 2004; Pracontal, 2004; Sokal \& Bricmont, 2001). Assim, tem-se uma ciência que, a partir de um conjunto de métodos e de procedimentos específicos, tenta elucidar questões ou iluminar pontos obscuros da realidade. Os processos de desenvolvimento do conhecimento científico iniciamse onde cessam os questionamentos do cotidiano comum.

\footnotetext{
* Esta parte do texto é resumo de uma das seções da dissertação e contém os principais aspectos do desenvolvimento do pensamento (filosófico) científico no Ocidente.
}

Manifestando-se em situações diversas nem sempre por meio de procedimentos racionalmente rigorosos (Granger, 2002), a ciência surge, inicialmente, como pensamento. Isto pode parecer um tanto vago, mas não é exagero lembrar que a ciência manifesta-se, nos primórdios do pensamento ocidental, como um conhecimento filosófico.

Por volta do século VI a.C., o ser humano propõe-se a questionar a origem das coisas do mundo. Para isso, é necessário que se distancie dos imperativos mitológicos regentes, até então, dos eventos terrestres (Andery, 2003).

Conta-se, a partir desse momento, com o início do pensamento racional no Ocidente e, conseqüentemente, com as primeiras incursões no campo científico. Vale ressaltar que a ciência, tal qual é conhecida hoje, iniciase por volta do século XVIII. Portanto, o conhecimento que pode ser chamado de filosófico científico surge e se desenvolve ao longo dos séculos como tentativa de "rigoroso" exercício da razão (Marcondes, 2001).

Ao período inicial da razão no Ocidente dá-se o nome de Idade Antiga (Clássica). Como primeiros pensadores (filósofos cientistas) pode-se citar Tales de Mileto (623546 a.C. aproximadamente), Anaximandro (610-547 a.C.), Anaxímenes (588-524 a.C.), Pitágoras (570-490 a.C. aproximadamente), Heráclito (500 a.C.), Parmênides (510-470 a.C. aproximadamente), até se chegar a Sócrates (469-399 a.C.), a Platão (427-347 a.C.) e a Aristóteles (384-322 a.C.). Há uma diferença a ser apontada entre esses filósofos. Os primeiros buscam a "essência" (princípio primordial) das coisas do mundo, já os últimos direcionam suas indagações ao próprio ser, não se importando muito, por exemplo, com a natureza.

As indagações irão se multiplicar e se diversificar em correntes distintas. Nada mais natural, pois não estão imunes a mudanças de comportamento nas quais a grande influência é social e histórica. Sendo esses períodos históricos propícios a acontecimentos, é a partir deles que se justificam as transições.

Pode-se dizer que a Idade Antiga (Clássica) encerra-se com o início do período Cristão (século I), porém é importante frisar que, em tais períodos, as influências de pensamento e de crenças não são nem poderiam ser totalmente extintas. Há um pensamento dominante, mas isso não significa que novos pensamentos não possam surgir ou que antigas doutrinas não sejam mantidas (Koyré, 1991). Estes "recortes" são necessários apenas para a localização temporal e espacial de eventos 
históricos que venham a auxiliar o acompanhamento do desenvolvimento do pensamento filosófico científico.

Havendo suposto período de transição (século I ao século IV - Império Romano), a Idade Média inicia-se no século V (Simaan \& Fontaine, 2003). Esse é um período dogmático, no qual a Igreja impõe sua doutrina de servidão. A natureza não deve ser profanada. O pensamento grego era considerado pagão, pois tentava encontrar a "essência" das coisas e do ser na terra ou no próprio ser humano, sendo que, para os medievos, tudo era constituído a partir da vontade divina; apenas Deus revelava. Destacam-se dois pensadores mais importantes da época: Santo Agostinho (354-430) e São Tomás de Aquino (1225-1274).

A grande questão desse período é a forma como a Igreja utiliza a doutrina cristã. $O$ ser humano subjuga e pune em nome de Deus. Essa transferência de poder leva os indivíduos a cometer atos extremos, como, por exemplo, a condenação à morte na fogueira ou ao suplício. É bom esclarecer que esse não é um problema de crenças. As leis, os procedimentos e as doutrinas que regem tais crenças são feitas e/ou interpretadas pelo ser humano, cabendo a ele as conseqüências de sua má utilização.

O período medieval vê-se estabelecido e "vigiado" pela vontade religiosa. $\mathrm{O}$ pensamento filosófico científico se estagna. Pode-se dizer que o desenvolvimento do conhecimento não era bem aceito pelos que detinham o poder. Usavam da crença para se autoproclamarem representantes diretos de Deus na Terra. Essas pessoas não queriam ser incomodadas, e o livre pensar leva a questionamentos; portanto, tira-se a liberdade de pensamento do indivíduo, dizendo que o conhecimento verdadeiro é revelado por Deus.

Durante mais ou menos dez séculos (século V ao XV), esses princípios foram mantidos. Não há como se mentalizar uma Idade Média diferente. Tal como outros períodos, possui particularidades, sendo justas ou não. Porém, na esteira do desenvolvimento político e histórico, esses princípios começaram a ser questionados com mais freqüência. A Igreja perde a força e é obrigada a mudar de postura. O ser humano estava "liberto" para pensar.

O século XVI (ou XV) pode ser considerado como o início da Idade Moderna. A partir daí o ser humano reencontra a sua razão. A proposta é distanciar-se da crença e aproximar-se de um racionalismo absoluto.
A Idade Moderna comporta as primeiras e substanciais mudanças no desenvolvimento do pensamento filosófico cientifico. Copérnico (1473-1543) defende o heliocentrismo em oposição ao teocentrismo; Galileu (1564-1642) transporta o pensamento ao "experimento"; Bacon (1561-1626) aplica o método visando à objetividade científica, Descarte (1596-1650) desenvolve a metodologia em direção à verdade; e Newton (1642-1727) isola o objeto e entende o mundo como uma máquina que pode ser dividida em partes. A modernidade se caracteriza, portanto, pela supremacia do ser enquanto pensador e enquanto dominador do mundo pela razão. O ser humano transforma e domina tudo ao seu redor. Não é possível conceber qualquer evento que fuja à sua inteligibilidade. Os fenômenos devem ser explicados racionalmente. A neutralidade no pensamento, agora também experimentado e metodologicamente orientado, é o mito dos modernos. (Kujawski, 1988).

O mito da ciência que tudo explica e que a tudo domina, tendo por fundamento uma razão que se considera única e universal, começa a sofrer críticas dentro da própria modernidade. O século XIX comporta parte das críticas contrárias às doutrinas e aos dogmas defendidos pela razão "absoluta". Trata-se de um princípio de desligamento que nasce a partir das abordagens de, por exemplo, Nietzsche (1844-1900), Schopenhauer (17881860) e Kierkegaard (1813-1855). A razão está em crise (Novaes, 1996; Feyerabend 1991) e necessita de "novas" abordagens. Mais adiante, em finais do século XIX e início do século $\mathrm{XX}$, a própria ciência, em sua vertente experimental, depara-se com um universo que se forma e se transforma muito além de suas possibilidades de explicação.

Apesar das controvérsias em torno do término da Idade Moderna, toma-se como referência para o surgimento de um "novo" período o século XX. Este período é chamado de Pós-Moderno.

A pós-modernidade é marcada por profundas transformações em diversos setores do conhecimento e do próprio cotidiano humano. Os avanços industriais, as guerras, o comércio, a produção em massa, a divisão política e econômica dos países, assim como o impulso tecnológico, interferem e sofrem interferência quase que direta do pensar e do fazer ciência. Estas questões fazem com que o ser humano se obrigue a ter posturas diferenciadas, ou seja, cada vez mais o mundo se pluraliza. A pluralização, por sua vez, também exige um pensamento plural. 


\section{PERSPECTIVAS HISTÓRICAS DA PÓS- MODERNIDADE}

O debate em torno do pós-moderno* tomou força a partir da década de 1970, com o desenvolvimento de novas tecnologias e das prováveis conseqüências advindas de seu alto poder informacional (Dupas, 2000). Porém, remonta a muito antes dessa data a aparição do termo pós-moderno. Ele surgiu pela primeira vez, segundo Anderson (1999), na década de 1930, sob a idéia de um pós-modernismo que, então, era ligado à literatura. Criado dentro da literatura moderna como forma de crítica a essa última, o pós-modernismo foi usado para "[...] descrever um refluxo conservador dentro do próprio modernismo." Não tendo "maior ressonância”, somente após duas décadas é que o termo pós-moderno reapareceu "[...] no mundo anglófono, num contexto bem diferente como categoria de época e não de estética." Ganha uma "[...] difusão mais ampla a partir dos anos de 1970" (Anderson, 1999, p.10-20). Para Habermas (1990), foi “[...] na realidade a investigação da modernidade nos anos 50 e 60 que criou as condições para que a expressão 'pósmodernidade' passasse a ser corrente também entre os especialistas das ciências sociais" (Habermas, 1990, p.15)**.

Obra demarcadora nesse processo foi La Condition Postmoderne, de Jean-François Lyotad ${ }^{* * *}$, publicada em 1979 na França, tendo sua primeira tradução para o português em 1986. A obra pontua a relevância do pós-

* Freyre (2001), já em 1973, alertava para alguns perigos ou "desafios" trazidos pela pós-modernidade com a "superindustrialização" da Europa e dos EUA (Freyre, 2001, p.192). A obra marca, até o momento, a primeira abordagem em profundidade no Brasil sobre a pósmodernidade. Não apenas sobre a pós-modernidade, mas sobre suas características e a condição do ser humano diante de novos eventos sociais, tecnológicos e científicos. Sobre o "homem" brasileiro na pós-modernidade, Freyre (2001) enumera uma multiplicidade, tipicamente pós-moderna, de fatores a serem considerados em sua análise, tais como antropológicos, biológicos, ecológicos, culturais, políticos, religiosos, filosóficos, tecnológicos, científicos, sociais, enfim, fatores de complexidade. Por outro lado, a temática "pós-modernidade" apenas ganha a atenção das publicações seriadas no Brasil a partir da década de 1980. Trigo (1991) faz um apanhado dessas publicações que povoaram a década de 1980 e levaram a discussão sobre a pósmodernidade a um público menos especializado. Sobre a pósmodernidade na América Latina, ver Toro (1997).

** Paiva (2002) caracteriza a teoria habermasiana como "autoritária", pois fundamenta-se na noção de consenso. Consenso não significa vontade coletiva e, muito menos, democracia. A proposta de Habermas para a recuperação de um "[...] projeto iluminista que pudesse desatar os 'nós' da chamada pós-modernidade nos parece problemático" (Paiva, 2002, p.186-187). Nesse sentido, Rouanet (2000) propõe algo parecido. Chama-o de "Novo Iluminismo" ou "Iluminismo positivo" (Rouanet, 2000, p. 30).

*** Jean-François Lyotard foi influente pensador francês do século XX (faleceu em 1998, aos 73 anos). A associação da figura de Lyotard ao pós-moderno é quase inevitável. Apesar de ter publicado mais de duas dezenas de livros, foi com La Condition Postmoderne que ficou conhecido no mundo acadêmico. moderno como legítima condição representativa da atualidade (Connor, 1993). Ampliam-se as formas e as técnicas de construção do conhecimento, os consensos teóricos se diluem, dando passagem à interdisciplinaridade, uma das principais marcas na construção do saber e figura marcante no debate sobre a legitimidade científica em finais do século XX. Nota-se também que o debate sobre o conceito de um pós-modernismo artístico, arquitetônico (Subirats, 1984) e literário é bem mais antigo do que o debate ao redor da pós-modernidade. (Anderson, 1999; Kumar, 1997; Coelho Neto, 2001).

Coelho Neto (2001) afirma que a "[...] idéia de pósmodernidade tem hoje no mínimo trinta anos. Escavando na história em busca do instante crucial de um eventual big bang pós-moderno, é possível admitir que essa seja, mesmo, uma idéia centenária” (Coelho Neto, 2001, p.7). Existem diversas maneiras de conceber e de compreender a história e a própria definição de pós-moderno. Mais difícil se torna tal discussão ao englobar-se a pósmodernidade e o pós-modernismo. De fato, segundo Lechte (2002), existem várias maneiras de se compreender o que seja pós-modernidade. O autor destaca o pensamento de Lyotard e de Baudrillard em que ambos questionam a "[...] moderna epistemologia baseada em uma nítida distinção entre sujeito e objeto." Há, também, a crise das "metanarrativas", significando que "[...] nenhuma explicação global de conduta é crível em uma era de racionalidade proposital." Lechte diz que o período moderno estava baseado na "produção" e o pós-moderno, na "reprodução" (Lechte, 2002, p. 257).

Apesar de propor a distinção entre pós-modernidade e pós-modernismo, Eagleton (1998) “opta” por usar este último para abranger também o significado do primeiro. “Optei por adotar o termo mais trivial 'pós-modernismo' para abranger as duas coisas, dada a evidente e estreita relação entre elas" (Eagleton, 1998, p.7).

Eagleton (1998) diferencia pós-modernismo e pósmodernidade referindo-se ao primeiro como "uma forma de cultura contemporânea" e ao segundo como um "período histórico específico". Nesse caso, a pósmodernidade é uma "[...] linha de pensamento que questiona as noções clássicas de verdade, razão, identidade e objetividade, a idéia de progresso ou emancipação universal, os sistemas únicos, as grandes narrativas ou os fundamentos definitivos de explicação" (Eagleton, 1998, p.7). São, enfim, os postulados questionados, no final do século XIX e no decorrer do século XX, pela própria ciência. Eagleton também destaca alguns eventos, como o avanço do capitalismo no Ocidente, a sociedade de serviços, a "globalização" da 
tecnologia. É o triunfo das "[...] indústrias de serviços, finanças e informação [...].” Já o pós-modernismo é caracterizado como um estilo cultural que procura refletir essa "[...] mudança memorável por meio de uma arte superficial, descentrada, infundada, auto-reflexiva, divertida, caudatária, eclética e pluralista [...].” Segundo o autor, o pós-modernismo mistura cultura "elitista" e cultura "popular", a arte confunde-se com o cotidiano. Porém, o domínio ou a disseminação dessa cultura pósmoderna, no sentido de averiguar se possui um certo "[...] acolhimento geral ou constitui apenas um campo restrito da vida contemporânea, é objeto de controvérsia" (Eagleton, 1998, p. 7).

O mesmo sentido segue Santos (2001), quando se refere ao pós-modernismo como o período que representa as "[...] mudanças ocorridas nas ciências, nas artes e nas sociedades avançadas desde 1950 [...].” Santos (2001) lembra que o pós-modernismo tem origem na arquitetura e, como já mencionado, na tecnologia, a partir da década de 1950. Na década de 1960 tem como referencial a "arte pop"; em 1970 sua principal característica é a crítica filosófica à "cultura ocidental". Hoje "amadurece", "[...] alastrando-se na moda, no cinema, na música e no cotidiano programado pela tecnociência (ciência + tecnologia ...sem que ninguém saiba se é decadência ou renascimento cultural." (Santos, J. F. dos, 2001, p.7-8). Efetivamente, os aspectos artísticos, arquitetônicos, literários, musicais - enfim, a cultura em suas possíveis características e relações - passaram por significativos processos de mudança na pós-modernidade.

Rouanet (2000) não é partidário da idéia de vigência da pós-modernidade, pelo contrário, propõe um "novo Iluminismo", mesmo afirmando que tem a "[...] pretensão de contribuir a sério para esse trabalho [...]" (Rouanet, 2000, p.30). Afirma o autor que é "inquietante" a idéia de se estar vivendo um período pós-moderno, pois isso parece significar que "[...] deixamos de ser contemporâneos a nós mesmos.” Propõe aceitar, provisoriamente e em termos filosóficos, que se vive em um período pós-moderno, pois esta é a "opinião de um grande número de pessoas", considerando que parte dessas pessoas não são "lunáticas" (Rouanet, 2000, p.229). A utilização do termo pós-moderno em diferentes contextos - históricos, culturais, econômicos, filosóficos e científicos - causa certa "irritação", na opinião do autor, quando se necessita de uma definição que obedeça "[...] a alguns preceitos elementares de lógica e em todo caso ao princípio da identidade: o pós-moderno não pode ser ao mesmo tempo tudo e seu contrário" (Rouanet, 2000, p.230). Porém, efetivamente é isto o que é o pósmoderno: o tudo e o seu oposto. Há, portanto, uma indefinição no próprio espírito da pós-modernidade. Essa indefinição se estabelece em contrapartida à cristalização: a certeza da incerteza. Uma definição impõe limites, categoriza e reduz. A pós-modernidade existe pela possibilidade de se negarem os limites, as categorias e as reduções impostas pelo pensamento moderno.

Jameson (2000) propõe que se entenda o "[...] conceito de pós-moderno como uma tentativa de pensar historicamente o presente em uma época que já esqueceu como pensar dessa maneira." Segundo o autor, há certa ambigüidade neste sentido, pois o "[...] conceito ou 'exprime' (não importa se de modo distorcido) um irreprimível impulso histórico mais profundo ou efetivamente o 'reprime' e desvia [...]." Parece que o pósmoderno tenta preencher seus espaços vazios com a "enumeração de mudanças e modificações", buscando rupturas e eventos "[...] em vez de novos mundos, busca o instante revelador depois do qual nada mais foi o mesmo [...]" (Jameson, 2000, p.13).

Coelho Neto (2001) parece entender da mesma maneira essa característica pós-moderna, ou seja, a principal preocupação da pós-modernidade não reside no resgate do passado como forma de "memorialismo" ou como forma de "recuperação imaginária e psicanalítica", mas, ao "[...] contrário disso: o recurso à historiografia se dá como instrumento de alteração do passado, não de sua reconstrução e preservação" (Coelho Neto, 2001, p.94). Isso não significa que o pós-moderno seja anti-historicista. Caracteriza-se como um "novo historicismo", um "[...] novo dilema historicamente original, que envolve nossa inserção como sujeitos individuais em um conjunto multidimensional de realidades radicalmente descontínuas [...]" (Jameson, 2000, p.408). Assim, segundo Cotrim (2002), o "ponto comum" é a "[...] crítica ao projeto de emancipação humano-social através do desenvolvimento da razão" (Cotrim, 2002, p.226). Nesse caso, um dos princípios do que se chama "crise" epistemológica e/ou paradigmática, evidenciada ou mais discutida pelo menos no meio científico, é a crítica ao imperativo racional como única forma (válida) de explicação dos fenômenos cotidianos. Morin (2002b) afirma, por sua vez, que, se o mundo atual é considerado "não racional", o "[...] antigo o era ainda menos: mecanicista, determinista, sem eventos, sem inovação, ele era impossível; ele era 'inteligivel', mas tudo o que acontecia ali era completamente ininteligível..." (Morin, 2002b, p.85). Este é o contraponto entre o período Moderno e o Pós-Moderno. Dentro do pensamento científico ou filosófico científico (Marcondes, 2001), a racionalidade desmistifica-se a partir de uma concepção pluralista e não unívoca, como "queriam" os modernos. 
Da crise dos metarrelatos no processo de construção do saber baseado na "razão positiva", surge um mundo baseado em informação chamado de pós-moderno, e, paralelamente a ele, também se inicia a era do consumo e/ou sociedade pós-industrial (Lyotard, 2000). Assim, destacam-se quase que concomitantemente, em função da explosão informacional ocorrida no pós-Segunda Guerra Mundial, diversos fenômenos cotidianos, teorizados como sociedade pós-industrial (Bell, 1977a), sociedade pós-moderna (Lyotard, 2000), sociedade do consumo (Baudrillard, 1981) e sociedade da informação (Mattelart, 2002).

Elas surgiram e/ou estão baseadas no vertiginoso processo informacional que emergiu a partir de meados do século XX. Estudillo-García (2002) diz que um novo paradigma surge com o desenvolvimento, a partir da década de 1970, das tecnologias da informação e da comunicação, devido ao volume e acúmulo de informação (Estudillo-Garcia, 2001, p.191).

Mattelart (2002) afirma que a "[...] noção de sociedade da informação se formaliza na seqüência das máquinas inteligentes criadas ao longo da Segunda Guerra Mundial" (Mattelart, 2002, p.8). Lyotard (2000) parece ver com naturalidade tal situação. Para ele, as "máquinas informacionais" afetarão a "[...] circulação dos conhecimentos, do mesmo modo que o desenvolvimento dos meios de circulação dos homens (transportes), dos sons e, em seguida, das imagens (mídia) o fez" (Lyotard, 2000, p.4).

Baudrillard (1994), em tom mais crítico e referindo-se à comunicação de massa, diz que o que afeta as massas é justamente a tentativa de dar-lhes o que se acha ser o "melhor" para elas. As massas não querem a aproximação com a racionalização. Querem “espetáculo”. Querem fazer parte dos "jogos" de superfície, não querem se converter à "seriedade dos conteúdos". Elas "[...] querem apenas signos, elas idolatram o jogo de signos e de estereótipos, idolatram todos os conteúdos, desde que eles se transformem numa seqüência espetacular" (Baudrillard, 1994, p.14-15). Um pouco antes, Bell (1977b) já dizia que a sociedade pós-industrial é, "basicamente", uma sociedade de informação e do conhecimento (Bell, 1977b, p.3) por dois motivos: o primeiro diz respeito às inovações decorrentes da "[...] pesquisa e do desenvolvimento (mais diretamente, existe um novo relacionamento entre ciência e a tecnologia, em virtude da centralidade do conhecimento teórico) [...]"; o segundo motivo é o próprio conhecimento que, pelo seu desenvolvimento, abre novos campos de trabalho (Bell, 1977a, p.241). Nesse caso, o “[...] pós-modernismo é coisa típica das sociedades pós-industriais baseadas na informação [...]” (Santos, J. F. dos, 2001).

A informação está, portanto, estreitamente ligada ao período pós-moderno. A ciência da informação na pósmodernidade, além de necessitar de debates em torno de conceitos, requer maiores incursões em e através de seu próprio objeto de estudo (Kobashi, Smit \& Tálamo, 2001, p.3). González de Gómez (1993) lembra que as crises paradigmáticas na ciência e o descrédito da "razão dogmática" "[...] levarão a redefinir, entre outras coisas, quem são os atores que participam das esferas de circulação de informação científica, alargando o campo das parcerias possíveis entre os cientistas e a sociedade" (González de Gómez, 1993, p.221).

\section{BASES DO PENSAMENTO PÓS-MODERNO}

Não possuindo um "ideal comum e homogêneo", a pósmodernidade é um movimento, segundo Rodrigues (1999), contrário à tradição e à modernidade. Trata-se, pois, de um "[...] movimento crítico e de clarividência que actualmente se desenvolve com relação à pretensão de autonomia e de emancipação que os ideais modernos da razão iluminada e da autonomia do sujeito tentam prosseguir" (Rodrigues, 1999, p.70).

Assim como Lyotard (2000), Rodrigues (1999) diz que as "formas narrativas" foram superadas pela transcendência do próprio discurso, ou seja, a pós-modernidade incorpora, além dos princípios da razão e do progresso, o fundamento mítico. Não se sabe se a pós-modernidade é um problema, como afirma Rodrigues (1994), porém o pós-moderno constituiu-se, por um lado, com os movimentos de mudança implementados nos campos da política, da economia, da tecnologia e da ciência e, por outro, por meio de aspectos provavelmente de maior complexidade, como os filosóficos, os religiosos e os sociais.

Barbosa (2000), em texto de abertura da edição brasileira da obra de Jean-François Lyotard, A condição pós-moderna, diz que o "[...] que de fato vem desde então ocorrendo é uma modificação na natureza mesma da ciência (e da universidade) provocada pelo impacto das transformações tecnológicas sobre o saber" (Barbosa, 2000, p.7).

Os impulsos iniciais dessas ocorrências são os desvencilhamentos, os desligamentos, a individualização, o fragmentar-se para crescer, o personificar-se em uma unidade para distinguir-se das demais. A aceitação do indeterminado e a "[...] intensa desconfiança de todos os discursos universais ou (para usar um termo favorito) 'totalizantes' são o marco do pensamento pós-moderno" (Harvey, 2002, p.19). 
Novamente, evoca-se a figura de Lyotard (2000) sobre o seu decreto de falência dos metarrelatos, das grandes narrativas, apesar de, como se verá mais adiante, Nietzsche, um século antes de Lyotard, ter desenvolvido críticas ao pensamento que preconizava a verdade pura e absoluta por meio da razão. Segundo vários autores, Friedrich Wilhelm Nietzsche (1844-1900) figura como precursor da pós-modernidade (Vattimo, 2002; Lyon, 1998, p.17). Sua obra torna-se conhecida logo após sua morte e percorre todo o século XX, cada vez mais influente e atual, até chegar ao século XXI como "primeiro entre os primeiros", um gênio e um grande horizonte a explorar. Nesse sentido, considera-se que a volumosa obra de Nietzsche ainda está por ser analisada pela ótica pós-moderna ou a pós-modernidade ser estudada pela ótica nietzscheana. "Pode-se sustentar legitimamente que a pós-modernidade filosófica nasce na obra de Nietzsche [...]" (Vattimo, 2002, p.170)*.

Harvey (2002) cita, entre as linhas do pensamento pósmoderno, o pragmatismo (Richard Rorty) ${ }^{* *}$ e a filosofia da ciência (Thomas Kuhn e Paul Feyerabend). $O$ pragmatismo e a filosofia da ciência não surgiram na pós-modernidade, apenas passaram por mudanças, assim como a "[...] ênfase foucaultiana na descontinuidade e na diferença na história e a primazia dada por ele a 'correlações polimorfas em vez de causalidades simples e complexa' [...]"; como também o surgimento de novas teorias como a teoria do caos e da catástrofe e a abertura de centros tradicionalistas às grandes discussões éticas, políticas e antropológicas (Harvey, 2002, p.19).

As atuais linhas de debate presumem outras vias de construção do pensamento que podem ser chamadas de paradigmas. Para Kuhn (2001), os paradigmas emergem a partir de "anomalias" no processo científico. Essas anomalias são responsáveis pela emergência de um novo paradigma em substituição a um antigo.

Aparece, também, no cenário dessas transformações, a teoria de sistemas, que a não "diferenciação" entre as partes e o todo, ou seja, a diferença, incorporada ao sistema, faz surgir, segundo Luhmann (1998), um novo paradigma (Luhmann, 1998, p.31).

Na década de 1960, segundo Cristovão \& Braga (1997), começam os estudos em torno das desordens e das "[...] irregularidades em sistemas provocadas por alterações que são inicialmente tão pequenas que mal podem ser percebidas, mas que com o decorrer do tempo podem

\footnotetext{
* Ver Scopinho (2002).

** Sobre Richard Rorty, ver Ghiraldelli Júnior (1999). Sobre o pragmatismo, ver Cometti (1995); Shook (2002); Borradori (2003).
}

levar todo o sistema ao caos" (Cristóvão \& Braga, 1997, p.36-37). A esse processo deu-se o nome de teoria do caos. O caos, para Morin (2002b), é a base da ordem e da organização de todo o cosmos (Morin, 2002b, p.80). Dessa maneira, os postulados e dogmas da razão dão lugar ao princípio da incerteza (Prigogine, 2002 e 1996; Prigogine \& Stengers, 1994).

Pode-se ainda fazer referência à teoria da complexidade de Morin (1990, 1991 e 1996), à visão holística de Capra (1994) ou à teoria geral dos sistemas de Von Bertalanffy (1977), que surgiram para, paradoxalmente, evidenciar que existem estruturas inacessíveis à racionalização humana. O pensamento científico pós-moderno entende que o seu desenvolvimento se processa justamente através das lacunas que se expõem dentro da própria ciência. Onde não há lacunas não há o que desenvolver, o processo já está completo, concluiu-se e "perdeu-se" em sua finitude. Dessa maneira, a ciência moderna viu seus postulados serem destruídos pela idéia de um fim em si e serem reconstruídos na pós-modernidade pela idéia de infinito e da multiplicidade teórica. A nova estrutura social, política, econômica, religiosa, tecnológica e científica é, também, uma nova estrutura paradigmática, pois, como Kuhn (2001) já mencionara, o paradigma não influencia (e é influenciado) apenas pela ciência. Como exemplo pode ser usado o próprio crescimento do conhecimento a partir da década de 1950, com o desenvolvimento tecnológico do pós-Segunda Guerra Mundial. Morin (2002a) compara esse crescimento à torre de Babel, que "[...] murmura linguagens discordantes.” A informação precisa estar relacionada para gerar conhecimento, porém o que é abordado por Morin (2002a) é a quantidade dispensada (ruído) de informações e a capacidade do sistema de gerar mais informações. A informação está em toda parte, "[...] nas ciências como nas mídias, estamos afogados em informações" (Morin, 2002a, p.16-17).

Morin (2002a) afirma que esses problemas decorrem da própria inteligência que apenas consegue compreender reduzindo e unidimensionalizando as possibilidades de conhecimento. A incapacidade de tratar os problemas com maior profundidade transforma-se em um problema ainda maior, pois uma "[...] inteligência incapaz de perceber o contexto e o complexo planetário fica cega, inconsciente e irresponsável" (Morin, 2002a, p.15). Von Bertalanffy (1977) já dizia que "[...] explicar os fenômenos observáveis reduzindo-os à interação de unidades elementares investigáveis independentemente umas das outras [...]" é uma visão de ciência do "passado". Os problemas e os próprios sistemas "[...] não são inteligiveis mediante a investigação de suas respectivas partes 
isoladamente." (Von Bertalanffy, 1977, p.61). Para Morin (2002a), a teoria de sistemas "minou" a "validade de um conhecimento reducionista". A teoria de sistemas parte da idéia de que quase todos os objetos da "[...] física, da astronomia, da biologia, da sociologia, átomos, moléculas, células, organismos, sociedades, astros, galáxias formam sistemas, ou seja, conjuntos de partes diversas que constituem um todo organizado [...]". Segundo Morin, a teoria sistêmica foi, durante muito tempo, evitada no meio científico e, "ainda hoje, é marginalizada” (Morin, 2002a, p.26-27. Notas).

Segundo Von Bertalanffy (1977), existe uma conotação um tanto "mística" em torno da relação todo-parte, porque "o todo é mais que a soma entre as partes"; porém o próprio autor propõe-se a explicar por que isso ocorre, dizendo que "[...] consiste simplesmente em que as características constitutivas não são explicáveis a partir das características das partes isoladas." Ou seja, ao analisar as partes isoladas, ter-se-á a impressão de que são novas e/ou "emergentes" (Von Bertalanfy, 1977, p. 83). Morin (2002a) retoma a idéia afirmando que "[...] o conhecimento das partes depende do conhecimento do todo, como o conhecimento do todo depende do conhecimento das partes. Por isso, em várias frentes do conhecimento, nasce uma concepção sistêmica, onde o todo não é redutível às partes." (Morin, 2002a, p.88). Santos (2000), ao abordar o tema, diz que não importa a "opção" epistemológica, mas, estando a ciência em um "círculo hermenêutico", não se pode "[...] compreender qualquer das suas partes (as diferentes disciplinas científicas) sem termos alguma compreensão de como 'trabalha' o seu todo, e, vice-versa, não podemos compreender a totalidade sem termos alguma compreensão de como 'trabalham' as suas partes" (Santos, 2000, p.12).

A utilização do pensamento complexo proposto por Edgar Morin se deu em função de o autor dedicar parte de sua obra à reflexão e ao estudo do saber científico a partir de uma "nova" concepção epistemológica. Dessa maneira, preferiu-se dar destaque a Morin e à sua aproximação com os temas debatidos na ciência pós-moderna, apesar de o autor não utilizar explicitamente o termo pósmoderno.

A obra de Edgar Morin é destaque já há alguns anos e continua recebendo ampla divulgação na atualidade. Morin insere importante elemento no pensamento científico: a complexidade. A partir do pensamento complexo, a ciência relaciona-se a fatores sociais, antropossociais, sociobiológicos, geopolíticos, psicológicos, políticos, religiosos, tecnológicos e cosmológicos. O que Morin pretende é evidenciar a complexidade com a exploração e exposição da multiplicidade de relações que envolvem o processo de desenvolvimento do conhecimento e da vida do e ao redor do ser humano. Portanto, parecem interessar menos a Edgar Morin os fenômenos que fazem parte do cotidiano do ser humano do que o princípio de complexidade, que pretende introduzir como método para pensar as relações que envolvem esses fenômenos.

\section{PROLEGÔMENOS À PÓS-MODERNIDADE: A CRÍTICA}

O que é conhecimento? Como se conhece? A mente está ou não associada ao corpo? Onde e quando a informação se transforma em conhecimento? Perguntas fundamentais iguais a estas permeiam parte, talvez a maior, do itinerário filosófico-científico ocidental. Se, grosso modo, até Sócrates, a pergunta fundamental era sobre a origem das coisas, a partir dele o caminho passa a dirigirse ao próprio ser. O ser humano parece, então, admirarse com a sua própria razão, até que a fé postula que essa razão é proporcionada por uma força maior chamada Deus. A partir de então, a imagem de Deus irá figurar nas principais abordagens filosófico-científicas sobre o conhecimento, sua origem e as coisas que dele se originam. Mito, niilismo, crença, razão, entendimento, empirismo, experimento, inatismo, intuição, percepção, perspectiva e até espírito fazem parte de um amplo, polêmico, complexo e paradoxal trajeto do pensamento filosófico-científico dos pré-socráticos à atualidade (Simon, 2003; Reale \& Antiseri, 1991).

Nesse caso (ainda lembrando a idéia de Koyré (1991, p.16) de que "correntes de pensamento atravessam séculos inteiros, se superpõem e se entrecruzam."), parece ser um erro considerar a pós-modernidade como superação da modernidade. Um período de pensamento se transforma a partir de um outro período de pensamento. Porém, isto não significa, em hipótese alguma, que há uma superação nessa transição. Superação dá idéia de suplantação por algo melhor. Não parece que a Idade Média foi, por certo ponto de vista, melhor que o período Clássico. Mesmo que se considerasse uma tal superação ou superioridade da pós-modernidade em relação à modernidade, não haveria como sustentar a própria pósmodernidade, pois este período não parece comportar nenhum princípio único, e muito menos absolutizante. Uma pós-modernidade que supera, talvez, não possa ser pós-modernidade.

A discussão em torno da pós-modernidade, ao contrário de se pensar esgotada, está apenas começando. Pode ser que muito tenha sido discutido sobre o tema, porém 
estas discussões basearam-se em características específicas, tais como literatura, arquitetura, economia e o que se chama mass media.

O termo "pós-modernismo" comportou, durante algum tempo, aspectos relacionados às artes e à literatura. Aparentemente a distinção entre pós-modernidade e pósmodernismo é bem clara, revelando que alguns autores contemporâneos desferem críticas ao conceito errado.

A pós-modernidade realmente pode constituir-se como algo finalista. Um fim da história ou morte do sujeito. $\mathrm{O}$ solapamento do conceito de racionalidade. $\mathrm{O}$ nascimento do homem subjetivo. A decadência das estruturas sociais como família, igreja e o próprio Estado. Mas não é apenas isso. A pós-modernidade não é a "irmã má” da modernidade e muito menos sua tirana. A pósmodernidade nada mais é do que uma conseqüência natural de um mundo em desenvolvimento. E se desenvolvimento e progresso são argumentos (nostálgicos) para a manutenção da modernidade, a pósmodernidade não fica atrás nesse quesito, a não ser que não se possa considerar os avanços tecnológicos e científicos desse período.

O ser humano é caracterizado na pós-modernidade como um ser sem sentido. $\mathrm{O}$ indivíduo tornou-se insensível perante as mazelas de um mundo em constante clima de caos: a fome, a miséria, as guerras, as epidemias e tudo aquilo que enche páginas e mais páginas de livros, jornais e revistas, além dos programas jornalísticos nos mais variados tipos e formas de apresentação. São todos efeitos da pós-modernidade? Não. A pós-modernidade não surge dessa maneira.

A pós-modernidade parece ter se desenvolvido a partir da crítica ao pensamento dominante e à razão autoritária - isto não significa uma crítica à racionalidade (Carrilho, 1994; Granger, 1969; Saint-Sernin, 1998). Um de seus principais objetivos parece ser, desde finais do século XIX, mediante o pensamento de Nietzsche (Nietzsche, 1987, 2001, 2003, 2004a e 2004b), o de se postar criticamente a quase toda forma de pensamento que se pretenda único e universal (moral e dogmático) (Vattimo, 2002).

Em contrapartida, não parece haver razões para a utilização de expressões como: "à falta de melhor designação” (Santos, 2000, p.11), "a falta de melhor termo" (Rodrigues, 1999, p.70), ou ainda a proposta de projetos como um "novo Iluminismo" (Rouanet, 2000, p.30), na tentativa de retomar valores considerados perdidos ou "assassinados" pela pós-modernidade. Se o medo dos conservadores modernos (parece haver um paradoxo aqui) é o de uma ruptura com os princípios da modernidade, têm razão em estar preocupados, porém o fato de as conseqüências dessa modernidade ainda serem sentidas resulta em mal-entendidos. Geralmente, os protagonistas destas confusões são aqueles de espírito doutrinário e que querem implantar sistemas autoritários de subordinação e domínio. Se a sociedade pós-moderna vive em um mundo sem sentido, a sociedade moderna vive, como já mencionado, uma utopia (Kujawski, 1988).

Já passa do momento de se desmistificar a própria idéia de pós-modernidade. Apesar de não se ter uma definição "exata" do termo, a pós-modernidade não pode ser associada a todos os problemas da sociedade contemporânea. É necessário que os pensadores pósmodernos desenvolvam abordagens respectivas à temática. Não se pode confundir indecisão com flexibilidade. A pós-modernidade é caracterizada por esta flexibilidade que também é chamada erroneamente de fragmentação quando reduzida a aspectos midiáticos e tecnológicos. O desenvolvimento técnico e tecnológico, nestes moldes, já fragmenta bem antes da pósmodernidade. Dessa maneira, a saída é chamar a pósmodernidade de subjetiva, e pode até comportar este aspecto, mas não é o único. Aliás, não há a possibilidade de se captar este caráter de único na pós-modernidade. Eis algo do qual se tira proveito, porém não se manifesta enquanto evento da pós-modernidade.

A crítica ao pensamento redutor e simplificador recebe acolhimento e forças na pós-modernidade. Não foi a modernidade que cedeu espaço a um novo pensar. Esta tentativa de manutenção da modernidade enquanto linha mestra de pensamento na atualidade obriga-a revestir-se de uma espécie de irracionalidade - o que não seria uma desvantagem (Granger, 2002). O período moderno caracteriza-se justamente pela exaltação da razão enquanto princípio primeiro e único do conhecimento humano. Portanto, colocá-la como parâmetro ao desenvolvimento do pensamento na atualidade parece mutilar o próprio conceito de modernidade.

Distintamente, pode ser que um pensamento fundamentado na complexidade, entendida a maneira moriniana (Morin; Le Moigne, 2000) e utilizando o que este chama de "método", não estaria distante de uma realidade metodológica que precisa delimitar fronteiras e recortar objetos de estudo (Mendes, 2003). Isso apresenta efeitos paradoxais. Áreas distintas e historicamente separadas pelo que Morin chama de “cordão sanitário" (Morin, 2002b, p.24) estão invertendo suas posições. As ciências chamadas "duras" estão se flexibilizando, e as ciências "moles" estão se enrijecendo 
(Pena-Vega \& Nascimento, 2001, p.7). As revoluções dentro da ciência podem tanto partir das ciências humanas quanto das ciências naturais, desde que ambas sejam consideradas como ciência.

Considera-se a pós-modernidade, enquanto campo aberto ao conhecimento, uma das maiores chances de o ser humano desenvolver e absorver uma ciência que não precisa se fechar nem ser "simplista". Procura-se contextualizar não apenas a teoria moriniana na pósmodernidade, mas qualquer pensador que tenha se posicionado de maneira crítica perante estruturas de pensamento reducionista. Não se sabe dizer como alguns pragmáticos estão lidando com a pósmodernidade, pois "adocicaram" seus argumentos no passado e agora, de acordo com Rorty (apesar das críticas sofridas por Rorty sobre a sua visão do pragmatismo (Haack, 1998)), a pós-modernidade está um pouco "confusa" (Rorty, 2002, p.13-14).

Apesar das resistências, o que é natural e benéfico por um determinado ponto de vista, as áreas do conhecimento humano estão cada vez mais próximas e, o que é mais importante, criando e desenvolvendo conhecimento. Pode ser até que a ciência busque a religião e a religião busque a ciência (Peters \& Bennett, 2003). O conhecimento é em parte razão, em parte intuição, em parte sentimento, em parte espírito, em parte desconhecido. Vive-se por tudo isso e muito mais. O complexo não é o complicado ou o confuso. O complexo é o coerente e o responsável.

Mesmo que se moldem os princípios do conhecimento moderno a uma nova realidade, esta não lhe responderá, pois não se identifica neles. Os períodos de pensamento surgem para caracterizar o próprio pensamento, e não para se adaptar a gerações futuras. O conhecimento adquirido ao longo destes períodos servirá como base fundamental (a partir de reinterpretações) ao período subseqüente.

Os respectivos nomes que representam os períodos de pensamento não passam por uma avaliação para se saber se está bem posto o seu prefixo ou não. Eles apenas surgem. Quando surgem não significa que são eternos e libertos de críticas. Significa que algo está acontecendo. Quer dizer que há um processo sendo desenvolvido. Essas ocorrências não devem ser desqualificadas, pois quando ficam perceptíveis é porque já tomaram grande vulto e já possuem todo um contexto de justificação. Portanto, parece ser igualmente errado e até injusto buscar-se uma compreensão por meio de uma ruptura total. Não há rupturas totais. Talvez nem haja rupturas. $\mathrm{O}$ que existe são eventos que dão a impressão de rompimento. A história do conhecimento deixa bem claro que este não se elimina, mas se desenvolve e se transforma.

\section{PROCEDIMENTOS DE ANÁLISE}

Foram analisados textos de ciência da informação publicados em periódicos brasileiros com o objetivo de verificar se há neles ocorrência de termos identificados com a ciência pós-moderna.

O período de recorte escolhido foi de 1972 até 2002. Justifica-se tal seleção, tendo em vista que a década de 1970 é o período no qual surgem os primeiros cursos de ciência da informação no Brasil, dando início à produção científica em ciência da informação. De fato, aí surgiram os periódicos Ciência da Informação (1972), Revista da Escola de Biblioteconomia da UFMG (1972), que em 1996 se torna Perspectivas em Ciência da Informação, Revista de Biblioteconomia de Brasília (1973) e Revista Brasileira de Biblioteconomia e Documentação (1973). Em 1989 surge a revista Transinformação, seguida pelas revistas Informação EO Sociedade (1991) e Informação $\mathscr{E}$ Informação (1996). O ano de 2002 é tomado como período limite do recorte em função do próprio cronograma da pesquisa. Considerou-se o acervo da biblioteca da PUC-Campinas. O levantamento se encerrou no mês de junho de 2003; desse modo, as revistas que foram adquiridas pela biblioteca da PUC-Campinas, Campus Seminário, após essa data, não foram consideradas. A triagem de artigos foi feita manualmente em 258 volumes distribuídos em oito revistas. A tabela 1, a seguir, lista os volumes das revistas que foram analisadas e seus respectivos períodos de publicação, estabelecendo-se um comparativo na quantidade de volumes e, posteriormente (tabelas 3 e 5), na distribuição dos artigos.

O quadro 1, a seguir, apresenta as 23 categorias de análise, construídas com base em um referencial teórico desenvolvido sobre o pensamento filosófico-científico pósmoderno. O referencial consistiu em desenvolver uma estrutura teórica para explorar a temática abordada e identificar conceitos caracterizadores da ciência na pósmodernidade. O quadro 1 também apresenta os desdobramentos, considerados pertinentes, dessas categorias e contempla os autores identificados com a temática abordada. As variáveis, no quadro, são as próprias categorias, representadas por letras. O procedimento foi adotado para evidenciar a distribuição das categorias de análise nos textos, conforme exposto na tabela 4 , a seguir. 
Configuração epistemológica da ciência da informação no Brasil em uma perspectiva pós-moderna: análise de periódicos da área

TABELA 1

Apresenta os volumes das revistas analisadas

\begin{tabular}{|c|c|c|}
\hline Revistas & Volumes & Quantidade \\
\hline Ciência da Informação & $\begin{array}{l}\text { v.1, n.1, 1972; v.1, n.2, 1972; v.2, n.1, 1973; v.2, n.2, 1973; v.3, n.1, 1974; v.3, n.2, 1974; v.4, n.1, 1975; } \\
\text { v.4, n.2, 1975; v.5, n.1/2, 1976; v.6, n.1, 1977; v.6, n.2, 1977; v.7, n.1, 1978; v.7, n.2, 1978; v.8, n.1, } \\
\text { 1979; v.8, n.2, 1979; v.9, n.1/2, 1980; v.10, n.1, 1981; v.10, n.2, 1981; v.11, n.1, 1982; v.11, n.2, 1982; } \\
\text { v.12, n.1, 1983; v.12, n.2, 1983; v.13, n.1, 1984; v.13, n.2, 1984; v.14, n.1, 1985; v.14, n.2, 1985; v.15, } \\
\text { n.1, 1986; v.15, n.2, 1986; v.16, n.1, 1987; v.16, n.2, 1987; v.17, n.1, 1988; v.17, n.2, 1988; v.18, n.1, } \\
\text { 1989; v.18, n.2, 1989; v.19, n.1, 1990; v.19, n.2, 1990; v.20, n.1, 1991; v.20, n.2, 1991; v.21, n.1, 1992; } \\
\text { v.21, n.2, 1992; v.21, n.3, 1992; v.22, n.1, 1993; v.22, n.2, 1993; v.22, n.3, 1993; v.23, n.1, 1994; v.23, } \\
\text { n.2, 1994; v.23, n.3, 1994; v.24, n.1, 1995; v.24, n.2, 1995; v.24, n.3, 1995; v.25, n.1, 1996; v.25, n.2, } \\
\text { 1996; v.25, n.3, 1996; v.26, n.1, 1997; v.26, n.2, 1997; v.26, n.3, 1997; v.27, n.1, 1997; v.27, n.2, 1998; } \\
\text { v.27, n.3, 1998; v.28, n.1, 1999; v.28, n.2, 1999; v.28, n.3, 1999;v.29, n.1, 2000; v.29, n.2, 2000; v.29, } \\
\text { n.3, 2000; v.30, n.1, 2001; v.30, n.2, 2001; v.30, n.3, 2001; v.31, n.1, 2002; v.31, n.2, 2002; v.31, n.2, } \\
\text { 2002 }\end{array}$ & 71 \\
\hline $\begin{array}{l}\text { Revista da Escola de } \\
\text { Biblioteconomia da } \\
\text { UFMG }\end{array}$ & $\begin{array}{l}\text { v.1, n.1, mar./set. 1972; v.2, n.2, set. 1973; v.3, n.1, mar. 1974; v.3, n.2, set. 1974; v.4, n.2, set. 1975; v.5, } \\
\text { n.1, mar. 1976; v.5, n.2, set. 1976; v.6, n.1, mar. 1977; v.6, n.2, set. 1977; v.7, n.1, mar. 1978; v.7, n.2, } \\
\text { set. 1978; v.8, n.1, mar. 1979; v.8, n.2, set. 1979; v.9, n.1, mar. 1980; v.11, n.1, mar. 1982; v.11, n.2, set. } \\
\text { 1982; v.12, n.1, mar. 1983; v.12, n.2, set. 1983; v.13, n.1, mar. 1984; v.13, n.2, set. 1984; v.14, n.1, mar. } \\
\text { 1985; v.14, n.2, set. 1985; v.15, n.1, mar. 1986; v.15, n.2, set. 1986; v.16, n.1, mar. 1987; v.16, n.2, set. } \\
\text { 1987; v.17, n.1, mar. 1988; v.17, n.2, set. 1988; v.18, n.1, mar. 1989; v.18. n.2, set. 1989; v.19, n.1, mar. } \\
\text { 1990; v.19, n.1, (especial), mar. 1990; v.19, n.2, set. 1990; v.20, n.1, jan./jun. 1991; v.20, n.2, jul./dez. } \\
\text { 1991; v.21, n.1, jan./jun. 1992; v.21, n.2, jul./dez. 1992; v.22, n.1, jan./jun. 1993; v.22, n.2, jul./dez. } \\
\text { 1993; v.23, n.2, jul./dez. 1994; v.24, n.1, jan./jun. 1995;v.24, n.2, jul./dez. 1995 }\end{array}$ & 42 \\
\hline $\begin{array}{l}\text { Revista Perspectivas em } \\
\text { Ciência da Informação }\end{array}$ & $\begin{array}{l}\text { v.1, n.1, jan./jun. 1996; v.1, n.2, jul./dez. 1996; v.2, n.1, jan./jun. 1997; v.2, n.2, jul./dez. 1997; v.3, n.1, } \\
\text { jan./jun. 1998; v.3, n.2, jul./dez. 1998; v.4, n.1, jan./jun. 1999; v.4, n.2, jul./dez. 1999; v.5, n.1, jan./jun. } \\
\text { 2000; v.5, n.2, jul./dez. 2000; v.5, n.2, (especial) jul./dez. 2000; v.6, n.1, jan./jun. 2001; v.6, n.2, jul./dez. } \\
\text { 2001; v.7, n.1, jan./jun. 2002; v.7, n.2, jul./dez. } 2002\end{array}$ & 15 \\
\hline $\begin{array}{l}\text { Revista de Biblioteconomia } \\
\text { de Brasilia }\end{array}$ & $\begin{array}{l}\text { v.1, n.1, jan./jun. 1973; v.1, n.2, jul./dez. 1973; v.2, n.1, jan./jun. 1974; v.2, n.2, jul./dez. 1974; v.3, n.1, } \\
\text { jan./jun. 1975; v.3, n.2, jul./dez. 1975; v.4, n.1, jan./jun. 1976; v.4, n.2, jul./dez. 1976; v.5, n.1, jan./jun. } \\
\text { 1977; v.5, n.2, jul./dez. 1977; v.6, n.1, jan./jun. 1978; v.6, n.2, jul./dez. 1978; v.7, n.1, jan./jun. 1979; } \\
\text { v.7, n.2, jul./dez. 1979; v.8, n.1, jan./jun. 1980; v.8, n.2, jul./dez. 1980; v.9, n.1, jan./jun. 1981; v.9, n.2, } \\
\text { jul./dez. 1981; v.10, n.1, jan./jun. 1982; v.10, n.2, jul./dez. 1982; v.11, n.1, jan./jun. 1983; v.11, n.2, } \\
\text { jul./dez. 1983; v.12, n.1, jan./jun. 1984; v.12, n.2, jul./dez. 1984; v.13, n.1, jan./jun. 1985; v.13, n.2, } \\
\text { jul./dez. 1985; v.14, n.1, jan./jun. 1986; v.14, n.2, jul./dez. 1986; v.15, n.1, jan./jun. 1987; v.15, n.2, } \\
\text { jun./dez. 1987; v.16, n.1, jan./jun. 1988; v.16, n.2, jun./dez. 1988; v.17, n.1, jan./jun. 1989; v.17, n.2, } \\
\text { jul./dez. 1989; v.18, n.1, jan./jun. 1990; v.19, n.1, jan./jun. 1995; v.19, n.2, jul./dez. 1995; v.20, n.1, } \\
\text { jan./jun. 1996; v.20, n.2, jul./dez. 1996; v.21, n.1, jan./jun. 1997; v.21, n.2, jul./dez. 1997; v.22, n.1, } \\
\text { jan./jun. 1998; v.22, n.2, jul./dez. 1998; v.23/24, n.1, 1999/2000; v.23/24, n.1, 1999/2000; v.23/24, } \\
\text { n.3, 1999/2000; v.23/24, n.4, 1999/2000; v.25, n.1, jan./jun. 2001 }\end{array}$ & 48 \\
\hline $\begin{array}{l}\text { Revista Brasileira de } \\
\text { Biblioteconomia e } \\
\text { Documentação }\end{array}$ & $\begin{array}{l}\text { v.1, n.1/3, jan./mar. 1973; v.2, n.1/3, jun./set. 1973; v.2, n.4/6, out./nov. 1973; v.3, n.1/3, jan./mar. } \\
\text { 1974; v.4, n.4/6, abr./jun. 1974; v.4, n.1/3, jul./set. 1974; v.4, n.4/6, out./dez. 1974; v.5, n.1/3, } \\
\text { jan./mar. 1975; v.5, n.4/6, abr./jun. 1975; v.6, n.1/3, jul./set. 1975; v.6, n.4/6, out./dez. 1975; v.7, } \\
\text { n.1/3, jan./mar. 1976; v.7, n.4/6, abr./mar. 1976; v.8, n.1/3, jul./set. 1976; v.8, n.4/6, out./dez. 1976; } \\
\text { v.9, n.1/3, jan./mar. 1977; v.9, n.4/6, abr./jun. 1977; v.10, n.1/3, jul./set. 1977; v.11, n.1/2, jan./jun. } \\
\text { 1978; v.11, n.3/4, jul.dez. 1978; v.12, n.1/2, jan./jun. 1979; v.12, n.3/4, jul./dez. 1979; v.13, n.1/2, } \\
\text { jan./jun. 1980; v.13, n.3/4, jul./dez. 1980; v.14, n.1/2, jan./jun. 1981; v.14, n.3/4, jul./dez. 1981; v.15, } \\
\text { n.1/2, jan./jun. 1982; v.15, n.3/4, jul./dez. 1982; v.16, n.1/2, jan./jun. 1983; v.16, n.3/4, jul./dez. 1983; } \\
\text { v.17, n.1/2, jan./jun. 1984; v.17, n.3/4, jul./dez. 1984; v.18, n.1/2, jan./jun. 1985; v.18, n.3/4, jul./dez. } \\
\text { 1985; v.19, n.1/4, jan./dez. 1986; v.20, n.1/4, jan./dez. 1987; v.21, n.1/2, jan./jun. 1988; v.21, n.3/4, } \\
\text { jul./dez. 1988; v.23, n.1/4, jan./dez. 1990; v.24, n.1/4, jan./dez. 1991; v.25, n.1/2, jan./jun. 1992; v.25, } \\
\text { n.3/4, jul./dez. 1992 }\end{array}$ & 42 \\
\hline Transinformação & $\begin{array}{l}\text { v.1, n.1, 1989; v.1, n.2, 1989; v.1, n.3, 1989; v.2, n.1, 1990; v.2, n.2/3, 1990; v.3, n.1/2/3, 1991; v.4, } \\
\text { n.1/2/3, 1992; v.5, n.1/2/3, 1993; v.6, n.1/2/3, 1994; v.7, n.1/2/3, 1995; v.8, n.1, 1996; v.8, n.2, 1996; } \\
\text { v.8, n.3, 1996; v.9, n.1, 1997; v.9, n.2, 1997; v.9, n.3, 1997; v.10, n.1, 1998; v.10, n.2, 1998; v.10, n.3, } \\
\text { 1998; v.11, n.1, 1999; v.11, n.2, 1999; v.11, n.3, 1999; v.12, n.1, 2000; v.12, n.2, 2000; v.13, n.1, 2001; } \\
\text { v.13, n.2, 2001; v.14, n.1, 2002 }\end{array}$ & 27 \\
\hline Informação e Sociedade & $\begin{array}{l}\text { v.1, n.1, 1991; v.2, n.1, 1992; v.3, n.1, 1993; v.4, n.1, 1994; v.6, n.1, 1996; v.7, n.1, 1997; v.8, n.1, 1998; } \\
\text { v.9, n.1, 1999; v.9, n.2, 1999; v.10, n.1, 2000; v.12, n.2, 2002 }\end{array}$ & 11 \\
\hline Informação \& Informação & v.1, n.1, jan./jun. 1996; v.4, n.1, jan./jun. 1999 & 2 \\
\hline
\end{tabular}


QUADRO 1

Apresentaas categorias de análise

\begin{tabular}{|c|c|c|c|}
\hline Variáveis & Categorias de Análise & Desdobramentos & No \\
\hline $\mathrm{A}$ & Pós-moderno & Pós-modernismo; Pós-modernidade; Pós-moderna & 1 \\
\hline B & Epistemologia & $\begin{array}{l}\text { Abordagens Epistemológicas; Diferenças Epistemológicas; Rupturas } \\
\text { Epistemológicas; Revoluçôes Epistemológicas; Crises Epistemológicas; } \\
\text { Trajetórias Epistemológicas; "poli” epistemologia; Pressupostos } \\
\text { Epistemológicos; Domínio Epistemológico }\end{array}$ & 2 \\
\hline $\mathrm{C}$ & Filosofia da Ciência & Filosofia do Conhecimento & 3 \\
\hline $\mathrm{D}$ & Teoria do Conhecimento & Teoria da Ciência & 4 \\
\hline E & Complexidade & Teoria de sistemas; Relações de Complexidade & 5 \\
\hline $\mathrm{F}$ & Paradigmas & $\begin{array}{l}\text { Crises Paradigmáticas; Rupturas Paradigmáticas; Revoluções } \\
\text { Paradigmáticas; Novos Paradigmas; Mudanças Paradigmáticas }\end{array}$ & 6 \\
\hline $\mathrm{G}$ & Gaston Bachelard & Epistemologia & 7 \\
\hline $\mathrm{H}$ & Edgar Morin & Complexidade & 8 \\
\hline $\mathrm{I}$ & Karl Popper & Revoluções Cientifcas & 9 \\
\hline $\mathrm{J}$ & Thomas Kuhn & Paradigmas; Revoluções Científicas & 10 \\
\hline K & Mistura de Padrões & & 11 \\
\hline $\mathrm{L}$ & Diluição de Consensos & & 12 \\
\hline $\mathrm{M}$ & Mudança na relação Sujeito/Objeto & & 13 \\
\hline $\mathrm{N}$ & Crise das Metanarrativas & & 14 \\
\hline $\mathrm{O}$ & Desmistificação da Racionalidade & Desmistificação do Conhecimento; Desmistificação da Ciência & 15 \\
\hline $\mathrm{P}$ & Pluralismo & Pluralismo Conceitual; Pluralismo Metodológico & 16 \\
\hline$Q$ & Senso Comum & Ruptura com o Senso Comum; Novo Senso Comum & 17 \\
\hline$\widehat{R}$ & Jean François Lyotard & Pós-Moderno; Crise das Metanarrativas & 18 \\
\hline $\mathrm{S}$ & Revoluções Cientificas & & 19 \\
\hline $\mathrm{T}$ & Contínuo, Descontínuo & Construção: Desconstrução & 20 \\
\hline $\mathrm{U}$ & Teoria do Caos & & 21 \\
\hline $\mathrm{V}$ & Transversalidade & Pensamento Transversal & 22 \\
\hline $\mathrm{Y}$ & Contextos Relacionais & & 23 \\
\hline
\end{tabular}

No quadro 1 estão enumeradas as categorias de análise, evidenciando seus possíveis desdobramentos nos textos. Foram consideradas como categorias principais os termos pós-moderno e epistemologia. Procedeu-se, em seguida, à análise do corpus das revistas. Procurou-se analisar os seguintes constituintes dos artigos: geral, título, resumo, palavras-chave, tópicos e subtópicos. O item "geral" indica que, em algum momento, a categoria aparece no corpo do texto analisado, ou nos demais itens considerados. Por fim, 37 textos foram selecionados de acordo com as categorias de análise e a temática abordada pela pesquisa. A leitura foi orientada pelas categorias relacionadas e pelo referencial teórico. Alguns textos, mesmo não apresentando as categorias no título, resumo, palavras-chave, tópicos e subtópicos, foram selecionados, já que as apresentavam em seu conteúdo. Isso não significa que todas as revistas elencadas tiveram artigos analisados por conteúdo. Como pode ser observado, a primeira triagem concentrou-se nos itens título, resumo, palavras-chave, tópico e subtópico que apresentassem as categorias pós-moderno e epistemologia.
Os 37 textos relacionados passaram por uma releitura. No decorrer do processo, os textos foram analisados para a identificação das 23 categorias predeterminadas, levando-se em consideração o título, o resumo, as palavraschave, os tópicos e subtópicos e o desenvolvimento.

De acordo com a ocorrência das categorias selecionadas, foram desenvolvidas grades de análise, trazendo as ocorrências das categorias de análise nos artigos, além da distribuição das categorias nos próprios artigos. A tabela 2, a seguir, apresenta um comparativo da quantidade de artigos por categoria e por item de análise. Esse procedimento visa a relacionar as categorias de análise de acordo com suas ocorrências. A tabela 3, a seguir, apresenta um comparativo a partir da distribuição dos artigos por revista e por categorias de análise. A tabela 4, a seguir, traz o número de categorias (representadas por variáveis de A a $Y$ - ver quadro 1) apresentadas em cada texto. São identificados os textos que apresentam o maior número de ocorrências das categorias. Já a tabela 5, a seguir, indica o período (década) no qual mais se publicou, assim como a revista brasileira que possui o maior número de artigos sobre a temática abordada. 
Configuração epistemológica da ciência da informação no Brasil em uma perspectiva pós-moderna: análise de periódicos da área

TABELA 2

Distribuição dos artigos de acordo com as categorias de análise

\begin{tabular}{|l|c|c|c|c|c|}
\hline Categorias de Análise & Geral & Titulo & Resumo & Palavras-chave & Tópico e subtópico \\
\hline Pós-moderno & 18 & 9 & 6 & 5 & 4 \\
\hline Epistemologia & 22 & 2 & 5 & 3 & 0 \\
\hline Filosofia da Ciência & 9 & 0 & 0 & 1 & 0 \\
\hline Teoria do Conhecimento & 3 & 0 & 0 & 1 & 1 \\
\hline Complexidade & 10 & 0 & 2 & 0 & 4 \\
\hline Paradigmas & 24 & 4 & 4 & 2 & 0 \\
\hline Gaston Bachelard & 4 & 0 & 1 & 0 & 0 \\
\hline Edgar Morin & 2 & 0 & 0 & 0 & 0 \\
\hline Karl Popper & 9 & 0 & 1 & 0 & 2 \\
\hline Thomas Kuhn & 11 & 1 & 2 & 0 & 0 \\
\hline Mistura de Padrões & 0 & 0 & 0 & 0 & 0 \\
\hline Diluição de Consensos & 0 & 0 & 0 & 0 & 0 \\
\hline Mudança na relação Sujeito/Objeto & 3 & 0 & 0 & 0 & 0 \\
\hline Crise das Metanarrativas & 5 & 0 & 0 & 0 & 0 \\
\hline Desmistificação da Racionalidade & 2 & 0 & 0 & 0 & 0 \\
\hline Pluralismo & 8 & 0 & 1 & 0 & 0 \\
\hline Senso Comum & 5 & 0 & 1 & 0 & 0 \\
\hline Jean François Lyotard & 8 & 0 & 1 & 0 & 0 \\
\hline Revoluções Cientificas & 2 & 0 & 0 & 0 & 0 \\
\hline Continuo, Descontínuo & 9 & 0 & 1 & 0 & 0 \\
\hline Teoria do Caos & 2 & 0 & 2 & 2 & 0 \\
\hline Transversalidade & 2 & 0 & 0 & 0 & 0 \\
\hline Contextos Relacionais & 2 & 0 & 0 & 0 & 0 \\
\hline
\end{tabular}

TABELA 3

Quantidade de artigos por revista de acordo com as categorias de análise

\begin{tabular}{|c|c|c|c|c|c|c|c|c|}
\hline Categorias & $\begin{array}{l}\text { Ciência da } \\
\text { Informação }\end{array}$ & $\begin{array}{c}\text { Revista de } \\
\text { Biblioteconomia } \\
\text { de Brasilia }\end{array}$ & $\begin{array}{c}\text { Revista Brasileira de } \\
\text { Biblioteconomia e } \\
\text { Documentação }\end{array}$ & $\begin{array}{c}\text { Revista da Escola de } \\
\text { Biblioteconomia da } \\
\text { UFMG }\end{array}$ & $\begin{array}{l}\text { Perspectiva em } \\
\text { Ciência da } \\
\text { Informação }\end{array}$ & Transinformação & $\begin{array}{l}\text { Informação e } \\
\text { Sociedade }\end{array}$ & $\begin{array}{l}\text { Informação e } \\
\text { Informação }\end{array}$ \\
\hline Pós-moderno & 7 & 1 & 0 & 1 & 4 & 2 & 3 & 0 \\
\hline Epistemologia & 12 & 2 & 0 & 1 & 6 & 1 & 0 & 0 \\
\hline Filosofia da Ciência & 4 & 0 & 0 & 0 & 4 & 1 & 0 & 0 \\
\hline $\begin{array}{l}\text { Teoria do } \\
\text { Conhecimento }\end{array}$ & 0 & 0 & 0 & 1 & 1 & 1 & 0 & 0 \\
\hline Complexidade & 5 & 1 & 0 & 2 & 1 & 1 & 0 & 0 \\
\hline Paradigmas & 9 & 2 & 0 & 0 & 7 & 4 & 1 & 0 \\
\hline Gaston Bachelard & 2 & 0 & 0 & 1 & 1 & 0 & 0 & 0 \\
\hline Edgar Morin & 1 & 0 & 0 & 0 & 1 & 0 & 0 & 0 \\
\hline Karl Popper & 4 & 0 & 0 & 1 & 3 & 1 & 0 & 0 \\
\hline Thomas Kuhn & 6 & 0 & 0 & 0 & 5 & 0 & 0 & 0 \\
\hline Mistura de Padrões & 0 & 0 & 0 & 0 & 0 & 0 & 0 & 0 \\
\hline $\begin{array}{l}\text { Diluição de } \\
\text { Consensos }\end{array}$ & 0 & 0 & 0 & 0 & 0 & 0 & 0 & 0 \\
\hline $\begin{array}{l}\text { Mudança na relação } \\
\text { Sujeito/Objeto }\end{array}$ & 1 & 0 & 0 & 0 & 2 & 0 & 0 & 0 \\
\hline $\begin{array}{l}\text { Crise das } \\
\text { Metanarrativas }\end{array}$ & 2 & 0 & 0 & 0 & 2 & 1 & 0 & 0 \\
\hline $\begin{array}{l}\text { Desmistificação da } \\
\text { Racionalidade }\end{array}$ & 1 & 0 & 0 & 0 & 1 & 0 & 0 & 0 \\
\hline Pluralismo & 3 & 2 & 0 & 0 & 3 & 0 & 0 & 0 \\
\hline Senso Comum & 2 & 1 & 0 & 0 & 2 & 0 & 0 & 0 \\
\hline $\begin{array}{l}\text { Jean François } \\
\text { Lyotard }\end{array}$ & 5 & 0 & 0 & 1 & 1 & 1 & 1 & 0 \\
\hline $\begin{array}{l}\text { Revoluções } \\
\text { Cientificas }\end{array}$ & 2 & 0 & 0 & 0 & 0 & 0 & 0 & 0 \\
\hline $\begin{array}{l}\text { Contínuo, } \\
\text { Descontinuo }\end{array}$ & 6 & 1 & 0 & 0 & 2 & 0 & 0 & 0 \\
\hline Teoria do Caos & 2 & 0 & 0 & 0 & 0 & 1 & 0 & 0 \\
\hline Transversalidade & 2 & 0 & 0 & 0 & 0 & 0 & 0 & 0 \\
\hline $\begin{array}{l}\text { Contextos } \\
\text { Relacionais }\end{array}$ & 2 & 0 & 0 & 0 & 0 & 0 & 0 & 0 \\
\hline
\end{tabular}


TABELA 4

Distribuição das categorias de análise nos textos

\begin{tabular}{|c|c|c|c|c|c|c|c|c|c|c|c|c|c|c|c|c|c|c|c|c|c|c|c|c|}
\hline Textos & & & & & & & & & & & & & Variá & & & & & & & & & & & Total \\
\hline & $\mathrm{a}$ & $\mathrm{b}$ & $\mathrm{c}$ & $\mathrm{d}$ & $\mathrm{e}$ & $f$ & $\mathrm{~g}$ & $\mathrm{~h}$ & $\mathrm{i}$ & $j$ & $\mathrm{k}$ & 1 & $\mathrm{~m}$ & $n$ & 0 & $p$ & $q$ & $\mathrm{r}$ & $\mathrm{s}$ & $\mathrm{t}$ & $\mathrm{u}$ & $\mathrm{v}$ & $y$ & \\
\hline 1 & $X$ & $X$ & $\mathrm{X}$ & & $X$ & $X$ & & & $\mathrm{X}$ & $X$ & & & $\mathrm{X}$ & & & $X$ & & $\mathrm{X}$ & & $\mathrm{X}$ & & & $X$ & 12 \\
\hline 2 & & $X$ & & & $X$ & $X$ & & & & & & & & & & & & & & $X$ & & $\mathrm{X}$ & $X$ & 06 \\
\hline 3 & $\mathrm{X}$ & $X$ & $\mathrm{X}$ & & & & $\mathrm{X}$ & & & $\mathrm{X}$ & & & & & $\mathrm{X}$ & & & & & $X$ & & & & 07 \\
\hline 4 & & $X$ & & & & $\mathrm{X}$ & & & & $x$ & & & & & & & & & & & & & & 03 \\
\hline 5 & & $X$ & & & & & & & & & & & & & & & $\mathrm{X}$ & & & & & & & 02 \\
\hline 6 & & $\mathrm{X}$ & & & & $\mathrm{X}$ & $\mathrm{X}$ & & & $X$ & & & & & & & & $X$ & $\mathrm{X}$ & $\mathrm{X}$ & & & & 07 \\
\hline 7 & & & $\mathrm{X}$ & & $X$ & $X$ & & & $\mathrm{X}$ & $\mathrm{X}$ & & & & & & & 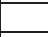 & & $X$ & & & & & 06 \\
\hline 8 & & & & & & & & & & & & & & & & & & & & $\mathrm{X}$ & & & & 01 \\
\hline 9 & $\mathrm{X}$ & $X$ & & & $\mathrm{X}$ & $\mathrm{X}$ & & $\mathrm{X}$ & . & . & & & & & & $\mathrm{X}$ & 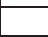 & & & & $\mathrm{X}$ & & & 07 \\
\hline 10 & & $\mathrm{X}$ & & & & $\mathrm{X}$ & & & & & & & & $\mathrm{X}$ & & $\mathrm{X}$ & & & & $\mathrm{X}$ & & & & 05 \\
\hline 11 & & $X$ & & & & $\mathrm{X}$ & & & $\mathrm{X}$ & $X$ & & & & & & & $\mathrm{X}$ & & & & & & & 05 \\
\hline 12 & $\mathrm{X}$ & & & & & $\mathrm{X}$ & & & & & & & & & & & & $\mathrm{X}$ & & & & & & 03 \\
\hline 13 & $X$ & $X$ & & & & & & & & & & & $X$ & & & & & $X$ & & & & & & 04 \\
\hline 14 & $\mathrm{X}$ & & & & & & & & $\mathrm{X}$ & & & & & & & & . & $\mathrm{X}$ & & & & & & 03 \\
\hline 15 & & $\mathrm{X}$ & & & & $\mathrm{X}$ & & & & & & & & & & $\mathrm{X}$ & & & & $\mathrm{X}$ & & & & 04 \\
\hline 16 & $\mathrm{X}$ & & & & & & & & & & & & & & & & & & & & & & & 01 \\
\hline 17 & & $\mathrm{X}$ & & & $\mathrm{X}$ & $X$ & & & & & & & & & & $\mathrm{X}$ & $\mathrm{X}$ & & & & & & & 05 \\
\hline 18 & $X$ & & & & $X$ & & & & & & & & & & & & & $\mathrm{X}$ & & & & & & 03 \\
\hline 19 & & $\mathrm{X}$ & & $\mathrm{X}$ & $\mathrm{X}$ & & $\mathrm{X}$ & & $\mathrm{X}$ & & & & & & & & & & & & & & & 05 \\
\hline 20 & $\mathrm{X}$ & $X$ & $\mathrm{X}$ & & & $\mathrm{X}$ & & & & & & & & & & & $\mathrm{X}$ & & & $\mathrm{X}$ & & & & 06 \\
\hline 21 & $X$ & $X$ & $\mathrm{X}$ & & & $\mathrm{X}$ & $\mathrm{X}$ & & $\mathrm{X}$ & $\mathrm{X}$ & & & $\mathrm{X}$ & $\mathrm{X}$ & $\mathrm{X}$ & & $\mathrm{X}$ & & & & & & & 11 \\
\hline 22 & & $\mathrm{X}$ & $\mathrm{X}$ & $X$ & & $\mathrm{X}$ & & & $\mathrm{X}$ & $\mathrm{X}$ & & & $\mathrm{X}$ & & & $\mathrm{X}$ & & & & & & $\mathrm{X}$ & & 09 \\
\hline 23 & & $x$ & & & $X$ & $\mathrm{X}$ & & $X$ & & $X$ & & & & & & & & & & $\mathrm{X}$ & & & & 06 \\
\hline 24 & & $X$ & & & & $\mathrm{X}$ & & & & $X$ & & & & & & $\mathrm{X}$ & & & & & & & & 04 \\
\hline 25 & $X$ & $X$ & $\mathrm{X}$ & & & $\mathrm{X}$ & & & $X$ & $X$ & & & & & & $X$ & & & & & & & & 07 \\
\hline 26 & $\mathrm{X}$ & & & & & $\mathrm{X}$ & & & & & & & & $\mathrm{X}$ & & & & $\mathrm{X}$ & & & & & & 04 \\
\hline 27 & $X$ & & & & & $\mathrm{X}$ & & & & & & & & & & & & & & & & & & 02 \\
\hline 28 & $X$ & & & & & & & & & & & & & $\mathrm{X}$ & & & & $\mathrm{X}$ & & & & & & 03 \\
\hline 29 & & $\mathrm{X}$ & & $\mathrm{X}$ & & $X$ & & & $\mathrm{X}$ & & & & & & & & & & & & & & & 04 \\
\hline 30 & & & $\mathrm{X}$ & & $X$ & $\mathrm{X}$ & & & & & & & & & & & & & & & & & & 03 \\
\hline 31 & $\mathrm{X}$ & $X$ & & & $X$ & & & & & & & & & & & & & & & & $\mathrm{X}$ & & & 04 \\
\hline 32 & & $X$ & $\mathrm{X}$ & & & $X$ & & & & & & & & & & & & & & & & & & 03 \\
\hline 33 & $\mathrm{X}$ & & & & & & & & & & & & & & & & & & & & & & & 01 \\
\hline 34 & & & & & & $X$ & & & & & & & & & & & & & & & & & & 01 \\
\hline 35 & $\mathrm{X}$ & & & & & & & & & & & & & & & & & & & & & & & 01 \\
\hline 36 & $X$ & & & & & & & & & & & & & & & & & & & & & & & 01 \\
\hline 37 & & & & & & $\mathrm{X}$ & & & & & & & & & & & & & & & & & & 01 \\
\hline
\end{tabular}

\section{TABELA 5}

\section{Apresenta a quantidade de artigos ao longo do período analisado (1972 a 2002)}

\begin{tabular}{|c|c|c|c|}
\hline Revistas & $1972-1981$ & $1982-1991$ & $1992-2001$ \\
\hline Ciência da Informação & 0 & 3 & 13 \\
\hline Revista de Biblioteconomia de Brasília & 0 & 0 & 3 \\
\hline Revista Brasileira de Biblioteconomia e Documentação & 0 & 0 & 0 \\
\hline Revista da Escola de Biblioteconomia da UFMG & 0 & 1 & 1 \\
\hline Perspectiva em Ciência da Informação & 0 & 0 & 7 \\
\hline Transinformação & 0 & 0 & 5 \\
\hline Informação e Sociedade & 0 & 1 & 3 \\
\hline Informação e Informação & 0 & 0 & 0 \\
\hline
\end{tabular}

Também foram retirados 68 fragmentos dos textos analisados, correspondentes às categorias de análise e que façam associações entre elas, porém não foi possível reproduzi-los aqui por motivo de espaço.

\section{Discussão dos resultados}

De acordo com o sugerido na tabela 3, a revista Ciência da Informação é a que apresentou maior ocorrência de categorias (quase todas as categorias de análise) e o maior número de artigos por categoria, seguida pela revista Perspectivas em Ciência da informação. Pode-se verificar também, pelas tabelas 2 e 3 , que as categorias que mais se apresentaram nos textos analisados foram pós-moderno, epistemologia e paradigmas, sugerindo a possibilidade de suas ocorrências em um mesmo texto.

A Revista Brasileira de Biblioteconomia e Documentação e a revista Informação e Informação não apresentaram nenhuma categoria; portanto, não existem artigos delas na amostra analisada. Também não se verificou a ocorrência das categorias "mistura de padrões" e 
"diluição de consensos" em nenhum dos textos selecionados.

A tabela 5 sugere que a concentração das publicações, de acordo com as categorias, deu-se a partir da década de 1990, sendo a maioria dos artigos veiculados pela Ciência da Informação. Mesmo já estando inserido no Brasil o debate sobre a pós-modernidade desde o início da década de 1980, parece que, em ciência da informação, como bem o demonstra a tabela 5, a temática pósmodernidade apenas ganha espaço a partir da década de 1990. De acordo com a tabela 4, os artigos de número 1 e 21 foram os que mais apresentaram ocorrências de categorias, 12 e 11 respectivamente, sendo que o primeiro é da revista Ciência da Informação e o segundo da Perspectivas em Ciência da informação. Nesse sentido, pode-se dizer que a Ciência da Informação é a que mais tem publicado artigos relacionados às temáticas epistemologia, pós-moderno e paradigmas em ciência da informação no Brasil, seguida pela revista Perspectivas em Ciência da Informação, apesar de essa última ter surgido apenas em 1996.

A baixa freqüência da ocorrência das categorias nos artigos e dos artigos nas revistas, sugerida pelas tabelas 2, 3, 4 e 5, também parece denunciar uma pequena e talvez superficial incursão no campo científico pósmoderno. Para um conjunto de 23 categorias (ver quadro 1), analisadas nos títulos, resumos, palavras-chaves, tópicos e subtópicos dos artigos, na primeira triagem, além do conteúdo, posteriormente, em uma média de 258 volumes de revistas (ver tabela 1), apenas 37 artigos foram selecionados de acordo com o item geral; desses, 16 artigos apresentaram categorias no item título, 23 no resumo, 15 nas palavras-chave e 20 nos tópicos e subtópicos. Além da baixa freqüência na ocorrência das categorias de análise (quadro 1) como se pode observar nas tabelas 2 e 3 , nota-se aparente superficialidade e limitação no debate em torno das categorias analisadas.

As revistas Perspectivas em Ciência da Informação (1996), Transinformação (1989) e Informação e Sociedade (1991) podem ser consideradas recentes, se comparadas com as revistas Ciência da Informação (1972), Revista da Escola de Biblioteconomia da UFMG (1972) e Revista Brasileira de Biblioteconomia e Documentação (1973). Apesar da grande quantidade de volumes a mais que as últimas possuem em relação às primeiras, vale dizer que as disparidades parecem não afetar a análise dos resultados, pois a maior parte dos textos selecionados pertence ao período de 1990 a 2000. A distribuição fica evidente pelas leituras realizadas, nas quais se pode notar que o debate sobre a pós-modernidade e as temáticas que a envolvem apenas começaram a se expressar a partir de 1990.

Nesse sentido, nota-se que poucos dos trechos coletados, quando se referem à mudança de paradigmas ou à pósmodernidade, tratam das rupturas e modificações dentro da própria ciência. Sendo a maioria destes artigos produzidos a partir da década de 1990, parece que a tendência foi o desenvolvimento de uma idéia de pósmodernidade ou de novos paradigmas relacionados aos processos de globalização e do tratamento, armazenamento e disseminação da informação por meio de novas tecnologias, em direção a uma sociedade da informação baseada no produto informação. $\mathrm{O}$ debate em torno desses eventos parece ser pertinente, porém talvez não se possa afirmar que seja suficiente para a construção de metodologias e conceitos que partam ou que se aproximem do que se chama de "novos paradigmas" da ciência.

Não parece que o debate tenha influenciado as estruturas teóricas da ciência da informação e, se isto ocorreu, foi de iniciativas isoladas. Nota-se, por exemplo, que grande parte dos trechos sobre a categoria "pós-moderno" trata a pós-modernidade como uma sociedade de informação, e não como uma pósmodernidade científica, sendo que uma ciência teria de tentar pensar cientificamente. Isto também parece apresentar-se na identificação de uma certa classificação em torno da ciência da informação enquanto kuhniana ou popperiana. Paradigmas não são apenas os de Thomas Kuhn (tentou-se, no caso, abordar os paradigmas "filosóficos" científicos ao longo da história do próprio pensamento, levando-se em consideração, quando possível, as complexidades, crises, rupturas, descontinuidades e revoluções que envolveram essa história; e Karl Popper, por sua vez, não parece ter elaborado um sistema de classificação, mas uma metodologia, um sistema de pensamento filosófico científico. Além do mais, esses dois filósofos da ciência travaram amplo debate sobre as "revoluções científicas", porém isso não parece ter sido abordado nos textos analisados. Corrobora isso o fato de a categoria de análise "revoluções científicas" apenas aparecer duas vezes nos textos selecionados (ver tabela 2). O pensamento kuhniano e o popperiano sugerem maior aproximação com a temática "revoluções científicas" (estando presente no título do livro de Thomas Kuhn e amplamente explorada na obra de Karl Popper), porém não parece que haja a mesma aproximação nos textos analisados em ciência da informação. 
Outro exemplo é o da categoria "complexidade". A teoria da complexidade ou epistemologia da complexidade é uma temática pós-moderna. Um de seus representantes é Edgar Morin. Porém, ao se analisarem as tabelas 2 e 3, parece que não há relação entre as categorias "complexidade" e "Edgar Morin". Isso também pode ser verificado com a leitura dos fragmentos que trazem a categoria "complexidade". Essa parece ser uma situação inversa à de Thomas Kuhn, em que o autor é associado, quase que invariavelmente, à noção de paradigma. Esse tipo de interpretação pode criar disparidades em relação ao próprio impacto que essas teorias tiveram no meio científico e o período no qual surgiram. Deve-se lembrar, porém, que o pensamento científico está em constante movimento no sentido de desenvolver tais teorias.

Muitas análises ainda poderiam e podem ser feitas de acordo com as informações aqui coletadas e sistematizadas, porém considera-se que o principal objetivo foi atingido, ou seja, discutir a atual situação de algumas temáticas relevantes ao estudo do estatuto científico da ciência da informação no Brasil e apontar para novos campos de discussão em torno do pensamento científico pós-moderno.

\section{Considerações finais}

O ser humano parece conscientizar-se de sua condição de ser falível. A diversidade é a característica mais marcante dessa espécie. $O$ cérebro pode ser uma das máquinas mais perfeitas que existem no mundo, proporcionando uma infinidade de interpretações, gerando associações e sensações que podem, ou não, transformar-se em conhecimento. É importante tentar entender que o conhecimento, científico ou não, pode sofrer interferência de vários tipos. Ao ser humano é necessária a vida em sociedade, em comunidades, com costumes e com culturas distintas. Isso não pode ser visto como problemas ou barreiras ao conhecimento. Esse é o ponto fundamental para desenvolvimento do conhecimento científico na pós-modernidade, ou seja, o pensamento aberto ao reconhecimento dessas distinções.

Pode-se dizer que a academia é um lugar privilegiado no qual essas concepções primeiro se manifestam. Os membros dessa comunidade (científica) devem estar atentos e conscientes de suas responsabilidades com relação a tais eventos. O envolvimento é inevitável, pois vive-se em um cotidiano no qual os resultados do desenvolvimento científico, por meio do grande aparato e ferramental tecnológicos, estão em quase toda a parte.
O que pode distinguir a realidade cotidiana (senso comum) de uma realidade acadêmica (científica) é, provavelmente, a maneira de pensar e de se abordarem tais características. Sendo a ciência um evento propriamente humano, tendo por ideal a estreita relação com a sociedade, qualquer disciplina pode ser científica, pois as disciplinas do conhecimento são criadas e desenvolvidas pelo próprio ser humano.

O pensamento na pós-modernidade não pode isolar, não pode reduzir e não pode ser simplista, ou seja, os objetos, os sujeitos e as próprias disciplinas científicas trabalham de acordo com a multiplicidade que envolve e que é característica "essencial" do ser humano e da sociedade.

Ressalta-se, a partir da pesquisa realizada, que, ao contrário do que se pensa, muitas temáticas pertinentes e necessárias ao desenvolvimento do chamado campo teórico da ciência da informação no Brasil ficaram, e parecem ainda estar, à margem do debate implementado nas revistas da área.

O desenvolvimento científico caracteriza-se por rupturas, revoluções e crises. Nunca houve, não há e, dificilmente, haverá linearidade no processo de construção científica.

A descontinuidade é reconhecida na pós-modernidade. Princípios de incerteza assumem posições centrais na construção do pensamento científico. A razão "positiva", evento primeiro e único de verdades absolutas, revela-se como o mito dos mitos.

A cência da informação parece estar atenta a essas temáticas, mas se fragmenta e se isola na superfície dos debates.

Para que teorias, metodologias e conceitos sejam construídos, é preciso que a área se distancie das abordagens superficiais e se aprofunde em contextos epistemológicos, múltiplos e complexos, revelando as correntes de pensamento nas quais se apóia. Talvez este seja o caminho para a consolidação da ciência da informação na pós-modernidade.

Artigo recebido em 08-06-2004 e aceito para publicação de 18 a $21 / 10 / 2004$.

Ci. Inf., Brasília, v. 33, n. 2, p. 49-66, maio/ago. 2004 
Configuração epistemológica da ciência da informação no Brasil em uma perspectiva pós-moderna: análise de periódicos da área

\section{REFERÊNCIAS}

ANDERSON, Perry. As origens da pós-modernidade. Rio de Janeiro : Jorge Zahar, 1999.

ANDERY, Maria Amália et al. Para compreender a ciência: uma perspectiva histórica. 12. ed. Rio de Janeiro : Garamond, 2003.

BARBOSA, Wilmar do Valle. Tempos pós-modernos. In: LYOTARD, Jean-François. A condição pós-moderna. 6. ed. Rio de Janeiro : José Olympio, 2000.

BAUDRILLARD, Jean. À sombra das maiorias silenciosas: o fim do social e o surgimento das massas. 4. ed. São Paulo : Brasiliense, 1994.

Sociedade de consumo. Lisboa : Edições 70, 1981.

BELL, Daniel. O advento da sociedade pós-industrial. São Paulo : Cultrix, 1977 a.

Welcome to the post-industrial society. In: Libraries in postindustrial society. Phoenix, EUA : Oryx, 1977b.

BORRADORI, Giovanna. A filosofia americana: conversações com Quine, Davidson, Putnam, Nozick, Danto, Rorty, Cavell, Maclntyre e Kuhn. São Paulo: Unesp, 2003.

CAPRA, Fridjof. O ponto de mutação. 16. ed. São Paulo : Cultrix, 1994.

CARRILHO, Manuel Maria. Jogos de racionalidade. Porto, Portugal : Edições ASA, 1994.

CHRISTOVÃO, Heloísa Tardin; BRAGA, Gilda. Ciência da informação e sociologia do conhecimento científico: a intertematicidade plural. Transinformação, v. 9, n. 3, p. 15-32, set./ dez. 1997.

COELHO NETO, José Teixeira. Moderno pós moderno: modos e versões. 4. ed. São Paulo : Iluminuras, 2001.

COLLINS, Harry; PINCH, Trevor. O golem: o que você deveria saber sobre ciência. São Paulo : Unesp, 2003.

COMETTI, J. P. Filosofia sem privilégios: desafios do pragmatismo. Porto, Portugal : Edições ASA, 1995.

CONNOR, Steven. Cultura pós-moderna: introdução às teorias do contemporâneo. 2. ed. São Paulo : Loyola, 1993.

COTRIM. Gilberto. Fundamentos da filosofia: história e grandes temas. 15. ed. São Paulo : Saraiva, 2002.

DUPAS, Gilberto. Ética e poder na sociedade da informação: de como a autonomia das novas tecnologias obriga a rever o mito do progresso. São Paulo: Unesp, 2000.

EAGLETON, Terry. As ilusões do pós-modernismo. Rio de Janeiro : Jorge Zahar, 1998.

ESTUDILLO GARCÍA, Joel. Elementos que conforman la sociedad de la información. Investigación Bibliotecológica, v. 15, n. 31, p. 161-194, jul./dic. 2001

FEYERABEND, Paul. Adeus à razão. Lisboa : Edições 70, 1991.

FREYRE, Gilberto. Além do apenas moderno. 2. ed. Rio de Janeiro : Topbooks, 2001.

GHIRALDELli JÚNIOR, Paulo. Richard Rorty: a filosofia do novo mundo em busca de mundos novos. Petrópolis : Vozes, 1999.

GONZÁlEZ DE GÓMEZ, Maria Nélida. A representação do conhecimento e o conhecimento da representação: algumas questões epistemológicas. Ciência da Informação, Brasília, v. 22, n. 3, p. 217 222, set./dez. 1993.
GRANGER, Gilles Gaston. A razão. São Paulo : Difusão Européia do Livro, 1969.

O irracional. São Paulo : Unesp, 2002.

HAACK, Susan. Quanto àquela frase 'estudando com um espírito literário...'. In: PINTO, Paulo Margutti et al. Filosofia analítica, pragmatismo e ciência. Belo Horizonte : UFMG, 1998.

HABERMAS, Jürgen. O discurso filosófico da modernidade. Lisboa : Publicações Dom Quixote, 1990.

HARVEY, David. Condição pós-moderna. 11. ed. São Paulo : Loyola, 2002.

JAMESON, Fredric. Pós-modernismo: a lógica cultural do capitalismo tardio. São Paulo : Ática, 2000.

KOBASHI, Nair Yumiko; SMIT, Johanna W; TÁLAMO, Maria de Fátima. A função da terminologia na construção do objeto da ciência da informação. DataGramaZero - Revista de Ciência da Informação, v. 2 n. 2, abr. 2001. Disponível em: <www.dgzero.org. Acesso em: 10 jun. 2002 .

KOYRÉ, Alexandre. Estudos de história do pensamento científico. 2. ed. Rio de Janeiro : Forense Universitária, 1991.

KUHN, Thomas S. A estrutura das revoluções científicas. 6. ed. São Paulo: Perspectiva, 2001.

KUJAWSKI, Gilberto de Mello. A crise do século XX. São Paulo : Ática, 1988.

KUMAR, Krishan. Da sociedade pós-industrial à pós-moderna. Rio de Janeiro : Jorge Zahar, 1997.

LECHTE, John. 50 pensadores contemporâneos essenciais: do estruturalismo à pós-modernidade. 2. ed. Rio de Janeiro : DIFEL, 2002.

LUCKESI, Cipriano Carlos; PASSOS, Elizete Silva. Introdução à filosofia: aprendendo a pensar. 4. ed. São Paulo: Cortez, 2002.

LUHMANN, Niklas. Sistemas sociales: lineamientos para una teoría general. México : Universidade Iberoamericana, 1998.

LYON, David. Pós-modernidade. São Paulo : Paulus, 1998.

LYOTARD, Jean-François. A condição pós-moderna. 6. ed. Rio de Janeiro: José Olympio, 2000.

MARCONDES, Danilo. Iniciação à história da filosofia. 6. ed. Rio de Janeiro : Jorge Zahar, 2001.

MATTELART, Armand. História da sociedade da informação. São Paulo: Loyola, 2002.

MENDES, Candido (Org.). Representação e complexidade. Rio de Janeiro: Garamond, 2003.

MORIN, Edgar. A cabeça bem feita: repensar a reforma, reformar o pensamento. 6. ed. Rio de Janeiro : Bertrand Brasil, 2002a.

MORIN, Edgar. Introdução ao pensamento complexo. 2. ed. Lisboa : Instituto Piaget, 1990.

MORIN, Edgar. O método 1: a natureza da natureza. Porto Alegre : Sulina, 2002b.

MORIN, Edgar. O paradigma perdido: a natureza humana. 5. ed. Lisboa: Europa-América, 1991.

MORIN, Edgar. O problema epistemológico da complexidade. 2. ed. Portugal : Europa-América, 1996.

MORIN, Edgar; LE MOIGNE, Jean Louis. A inteligência da complexidade. 2. ed. São Paulo: Peirópolis, 2000. 


\section{Marivalde Moacir Francelin}

NIETZSCHE, Friedrich Wilhelm. Obras incompletas. 4. ed. São Paulo : Nova Cultural, 1987. (Os pensadores).

PAIVA, Claúdio Cardoso de. O campo híbrido da informacão e da comunicação. In: AQUINO, Mirian de Albuquerque (Org.). O campo da Ciência da Informação: gênese, conexões e especificidades. João Pessoa: Editora Universitária, UFPB, 2002.

PENA-VEGA, Alfredo; NASCIMENTO, Elimar Pinheiro do. Edgar Morin: o passador de fronteiras. In: ____-_- (Org.). O pensar complexo: Edgar Morin e a crise da modernidade. 3. ed. Rio de Janeiro: Garamond, 2001.

PETERS, Ted; BENNETT, Gaymon. Construindo pontes entre a ciência e a religião. São Paulo: Unesp, 2003.

PRACONTAL, Michel de. A impostura científica em dez lições. São Paulo: Unesp, 2004

PRIGOGINE, Ilya. As leis do caos. São Paulo: Unesp, 2002.

PRIGOGINE, Ilya. O fim das certezas: tempo, caos e as leis da natureza. São Paulo: Unesp, 1996.

PRIGOGINE, Ilya; STENGERS; Isabelle. A nova aliança: a metamorfose da ciência. Brasília: Editora Universidade de Brasília, 1994.

REALE, Giovanni; ANTISERI, Dario. História da filosofia. 2. ed. São Paulo: Paulus, 1991.

RODRIGUES, Adriano Duarte. Comunicação e cultura: a experiência cultural na era da informação. 2. ed. Lisboa: Editorial Presença, 1999.

RORTY, Richard. Ensaios sobre Heidegger e outros. 2. ed. Rio de Janeiro: Relume Dumará, 2002. (Escritos filosóficos. v. 2).

ROUANET, Sérgio Paulo. As razões do Iluminismo. São Paulo: Companhia das Letras, 2000.

SAINT-SERNIN, Bertrand. A razão no século XX. Rio de Janeiro: José Olympio, 1998.

SANTOS, Boaventura de Sousa (Org.). Conhecimento prudente para uma vida decente: 'um discurso sobre as ciências' revisitado. São Paulo: Cortez, 2004.
SANTOS, Boaventura de Sousa. Introdução a uma ciência pós-moderna. 3. ed. Rio de Janeiro : Graal, 2000.

SANTOS, Jair Ferreira dos. O que é pós-moderno. São Paulo : Brasiliense, 2001.

SCOPINHO, Sávio Carlos Desan. Filosofia e sociedade pós-moderna: a reflexão de Gianni Vattimo para uma compreensão da crise dos paradigmas da modernidade. 2002. Dissertação (Mestrado) - Pontifícia Universidade Católica, Campinas, 2002.

SHOOK, John R. Os pioneiros do pragmatismo americano. Rio de Janeiro : DP\&A, 2002

SIMAAN, Arkan; FONTAINE, Joëlle. A imagem do mundo: dos babilônios a Newton. São Paulo : Companhia das Letras, 2003.

SIMON, Samuel (Org.). Filosofia e conhecimento: das formas platônicas ao naturalismo. Brasília : Editora da UnB, 2003.

SOKAL, Alan; BRICMONT, Jean. Imposturas intelectuais: o abuso da ciência pelos filósofos pós-modernos. 2. ed. Rio de Janeiro : Record, 2001.

SUBIRATS, Eduardo. Da vanguarda ao pós-moderno. São Paulo : Nobel, 1984.

TORO, Alfonso de. Postmodernidad y postcolonialidad: breves reflexiones sobre Latinoamérica. Madrid : Iberoamericana, 1997.

TRIGO, Luiz Gonzaga Godói. A pós-modernidade como categoria filosófica. 1991. Dissertação (Mestrado) - Pontifícia Universidade Católica, Campinas, 1991.

VATTIMO, Gianni. O fim da modernidade: niilismo hermenêutica na cultura pós-moderna. São Paulo : Martins Fontes, 2002.

VON BERTALANFFY, L. Teoria geral dos sistemas. 3. ed. Rio de Janeiro : Vozes, 1977.

O autor agradece à professora doutora Nair Yumiko Kobashi, pela orientação da dissertação de mestrado, à Capes, pela concessão da bolsa de estudos, e aos professores do Programa de Pós-graduação e funcionários da PUC/Campinas. 